\title{
Towards Net-Zero Energy in Hot-Dry Regions: Building Envelope Design Strategies for Single-Family Homes
}

\author{
Ahmed A. Alyahya ${ }^{1} \&$ Nawari O. Nawari ${ }^{2}$ \\ ${ }^{1}$ College of Architecture and Planning, Imam Abdulrahman Bin Faisal University, Dammam, Saudi Arabia \\ ${ }^{2}$ College of Design, Construction and Planning, University of Florida, Gainsville Fl., United States \\ Correspondence: Ahmed Alyahya, College of Architecture and Planning, Imam Abdulrahman Bin Faisal \\ University, Dammam, Saudi Arabia. E-mail: aaalyahya@iau.edu.sa
}

Received: November 7, 2017

Accepted: November 21, 2017

Online Published: May 30, 2018

doi: $10.5539 /$ jsd.v11n3p45

URL: https://doi.org/10.5539/jsd.v11n3p45

\begin{abstract}
Global climate change is serving as warning signs it gradually begins to capture the attention of people at large. Many actions have been and continue to be taken by governments and organizations to preserve the planet, which is impactful and needed. But conservation efforts are not exclusive to governments and large institutionsindividuals can contribute in multiple ways that will have ripple effects, one being the choice to build sustainable, net-zero energy homes. Building a house that is a net-zero energy requires many strategies.

One of the most compelling factors in reducing the home energy consumption, to then achieve a net-zero energy home especially in hot-dry regions, is the optimization of the building envelope performance. This paper discussed several building envelope design strategies that are suitable for homes in hot-dry regions and tested them.

The Methods including analyzing case study from Qater by using computer and were analyzed using Building Information Modeling (BIM) tools for energy simulation programs. All those strategies were applied to a design proposal for a house in Riyadh, Saudi Arabia, which is a hot-dry region. Further, the same simulation analyses were projected onto an identical house to the design proposal, but with a traditional, low-efficient building envelope.

The results showed that the house with the high-efficient building envelope had $48 \%$ less energy consumption than the one that has the low-efficiency envelope.

This research demonstrated the efficacy of the building envelope to reduce the energy consumption of single-family homes in hot-dry regions. The study outlines vital strategies for a high-efficient building envelope design in hot-dry areas that reaching net-zero energy homes and thus help to offset the negative impact of climate changes in arid areas.
\end{abstract}

Keywords: building envelope, net-zero energy, hot-dry climate, fenestration system, photovoltaics

\section{Introduction}

Should individuals sit comfortably with their arms crossed neglecting the environment around them? The conservation of the environment is not the government's obligation only, but rather the duty of every single person that can realize the weight of the current negative activities on the environment. Individuals can make a considerable change toward having a sustainable environment. One of the most significant aspects that individuals can contribute to saving the environment, and their money as well, is by making their homes sustainable, especially in regards to energy consumption. According to the United States Environmental Protection Agency EPA report, 2,039.32 million metric tons of carbon dioxide emissions in 2014 were from the combustion of fossil fuels to generate electricity (Inventory of U.S. Greenhouse Gas Emissions and Sinks, 2016). Moreover, the statistics of U.S. Energy Information Administration, the EIA, show that the total energy consumption of the residential sector in 2015 was 20,693 trillion Btu (Energy Consumption by Sector, 2016). Thus, $21.21 \%$ of the total energy consumption is from the residential sector. All these statistics illustrate that supplying buildings, especially the residential buildings, with electricity that is generated by fossil fuels causes significant, adverse impacts on the environment. Therefore, for this reason, net-zero energy buildings are a compelling alternative for conserving the environment. 
The crux to achieving a net-zero energy home is the building envelope's design. The building envelope's efficiency is the core of this research since it plays a crucial role in decreasing the home's demand for energy. Then, when the building consumes a lesser amount of electricity, the solar panels generate the remaining energy needed for the building.

The research concentrates on the wall, roof, fenestration and insulation systems design, also some factors that affect the building envelope such as orientation and inclusion of a courtyard. Then, how all these factors contribute to a decrease in energy demand to, in turn, produce from the renewable energy the same amount that a house needs. The entirety of this process will make the building a net-zero energy building. This research is used in many methods to illustrate that the high-efficiency building envelope can make a family home in hot-dry regions a net- zero energy home. Using simulation software that estimates the energy demand of a building and other software will help to make the study more realistic; Autodesk Green Building Studio and Insight 360 for Revit are examples of these methods. Further, a critical method is to learn and build off of previous case studies. The types of case studies that are used in the research are of homes that are in the hot-dry regions. In general, this study will illustrate to what extent does the building envelope of a single-family home in hot-dry regions contribute to the achievement of net-zero energy.

\section{Literature Review}

A wide variety of research has been done revolving around my area of interest. Every one of these sources focuses on an aspect of my study so that they will be very beneficial as a base for my research.

\subsection{Climate}

The most critical function of the building envelope is that it separates the interior environment of the building from the exterior environment. Consequently, the environment in which the building is located determines the features of the building envelope design. Building envelope design strategies in cold areas differ from those in hot or tropical areas; thus, every element of the building envelope from the array of materials to the fenestration design, and the insulation are dependent on a region's climate classification. The Koppen Climate Classification System organizes the world climate based on many factors including temperature, humidity, precipitation, atmospheric pressure, wind, and others. The following research will focus on the building envelope design strategies in hot-dry (desert) regions which is BWh based on Koppen Climate Classification System.

\subsection{Building Envelope}

The building envelope is "the shin supported by the skeleton of the structure, or the monolithic load-bearing wall mediates the environment and provides security" (Brock, 2005). In other words, the building envelope acts as the separator between the internal and the external environment of a building. The building envelope contains opaque components and fenestration systems. Opaque elements are walls, roofs, ground slabs, basement walls, and opaque doors; the fenestration systems combine windows, ventilators, skylights, and glazed doors. There are two primary functions of the building envelope; the first is that it serves as a barrier to protect occupants and the interior of the building from weather conditions, noise, pollution, etc. The second function is aesthetic, in that building envelopes set the tone for impression and style via the design and look of the facades.

The building envelope also plays a critical role in decreasing energy consumption. Its features are responsible for the heat gain and loss, and the amount of wind that is allowed to enter the building. To expound, there are external and internal thermal loads that a well-built envelope design should control of the heat transference through it. The external loads are mainly from the solar heat that transfers through windows, the envelope surfaces, and unwanted air infiltration in the building. The internal loads include the heat that comes from the artificial lighting systems, equipment, and body heat.

The basic design strategies for creating high-performance building envelopes include:

- Determining the orientation of the building and the massing form design depending on solar position.

- Maximizing the shading device to reduce the external thermal loads.

- Providing natural ventilation to decrease cooling loads that a building needs and to improve the air quality.

- Maximizing the natural light to be a substitutional of the artificial light.

- Optimizing the building envelope insulation system.

(Aksamija, 2013). 


\subsection{Net-Zero Energy}

The definition of net-zero energy as Hootman (2012) defined in his book Net Zero Energy Design: A Guide for Commercial Architecture in chapter 1 that "net zero energy is a measure of a building's energy performance, whereby it produces as much or more renewable energy as it uses over the course of a year in operation" (Hootman, 2012). The National Renewable Energy Laboratory (NREL) has classified the net-zero energy building to four systems. The ranking from A class which provides electricity to the building that is generated by renewable energy from sources located within the footprint of the building such as photovoltaics or wind turbine that mounted on the roof or integrated with the building facade, through D class which purchases renewable energy to operate the building (Hootman, 2012). Arid- hot regions get a great $t$ amount of sunlight for most of the year since the sky is always clear. Thus, solar power is a significant opportunity in this climate zone. solar power can be produced either by converting the sunlight to electricity by the photovoltaic cells or by converting the heat of the sun to energy as seen in solar solar thermal collectors. Solar power is not a recent innovation, it has been used since the 7th Century B.C. when people used to concentrate the sunlight by holding a magnifying glass above a small piece of wood for making fire (Maehlum, 2013). However, the idea of converting the sunlight to electricity started in 1839 by the French physicist Edmund Becquerel. The actual first photovoltaic cell was created in 1954 by David Chapin, Calvin Fuller and Gerald Pearson (Maehlum, 2013).

Nowadays, there is much variety in reaping the benefits of solar power. One common way to optimize solar power is through the use of photovoltaic cell, or what is called a solar panel. The cell gets its name from the conversion process of light (photons) to electricity (voltage), and thus is referred to as photovoltaic PV. There are many types of photovoltaics such as the flat-plate one which is made from silicon, the thin-film solar cells, and some PV that made from different materials than silicon. The flat-plate is the traditional PV, but nowadays, it is the most efficient one. Another type of PV is the thin-film solar cells that is second-generation of the PV. The thin-film solar cells made from amorphous silicon such as cadmium telluride. This type of PV is flexible, so it is used in many places such as the building elevations, rooftop shingles and tiles, and the glazing for skylights. The third generation of the PV is made from different materials than silicon like solar inks, solar dyes and conductive plastics (National renewable energy laboratory).

Furthermore, another technique to get the benefit from the solar power is by converting the heat of the sun to energy. The most popular way to achieve this is by using the solar thermal collectors which are "a particular type of heat extracting devices that convert solar radiation into thermal energy through a transport medium or flowing fluid" (Buker and Riffat, 2015). These solar thermal collectors are influential in any solar energy system. They absorb the sun radiation then, convert it to heat energy and transfer it to a working fluid such as air, water or a refrigerant, for several practical purposes (Kumar, Baredar and Qureshi, 2015).

Moreover, one of the most recent technologies in the solar power utilization is the photovoltaic-thermoelectric hybrid power generation system. The idea of the PV-TEG hybrid system is to utilize the wasted thermal energy of the concentrated photovoltaic system by attaching the thermoelectric generator to the back side of the photovoltaic module (Lamba and Kaushik, 2016). Studies show that the PV-TEG generates more power than the photovoltaic system alone. The efficiency of PV-TEG is around $23 \%$ which is more than photovoltaic which has an efficiency of about $19 \%$, so the PV-TEG efficiency is $25 \%$ more than that of the PV cells. (Zhu, Deng, Wang, Shen and Gulfam, 2016).

\subsection{Wall Systems}

The wall system consists of all the vertical opaque components of the building envelope. All of the materials, thermal insulation, thickness, wall assembly and finishes of the wall can be designed based on the climate of where the building is located and whether it needs heating or cooling. The ASCE Standard 11-Guideline for Structural Condition Assessment of Existing Buildings' book classifies the wall systems as load bearing or non-load bearing. The load-bearing wall system is a wall that carries any extra vertical load in addition to its selfweight; the non-load-bearing wall is that which does not support any vertical loads apart from its own weight. The components for both load-bearing and non-load-bearing wall systems can be identical (American, 2014).

\subsection{Roof System}

The building's roof is exposed to a substantial amount of solar radiation and plays a crucial role in heat gain in the hot-dry regions. In these areas, the roof should be well-insulated to reduce heat gains. Many approved strategies can improve the efficiency of the roof system. One of these strategies involves the efficacy of light color in reducing heat gain. Suehrcke, Peterson and Selby have shown in their study that light and dark colored roof surfaces have a significant disparity in heat gain. The equations in this paper illustrate accurate results of the average daily heat that a building's roof can absorb based on its color in hot climates. The study shows that in 
north Australia a light-colored roof has 30\% lower heat gain than a dark-colored roof (Suehrcke, Peterson and Selby, 2008). Another study by Prado and Ferreira discussed the effect of albedo, or reflectance of some building roofs' materials and how they are responsible for the heat gain. The results of this paper display that "the red and the white ceramics were the only materials among those that were measured that had reached surface temperatures lower than air temperatures" (Prado and Ferreira, 2005).

Another strategy that can cause a significant reduction of indoor temperatures is the application of a roof pond cooling system. Kharrufa and Adil experimented with a room in Baghdad, Iraq, which is a hot-dry region, and they measured the temperature inside the room in summer in three stages. The first measurement was in normal conditions without the pond, then another measurement with the pond on the top of the roof and without mechanical ventilation, and finally with mechanical ventilation. The results showed a noticeable enhancement in the indoor temperature of the room by around $11.0^{\circ} \mathrm{F}$ degrees cooler in the room with the pool than the room without, and $12.0^{\circ}$ cooler with a ventilated one. The measurements were taken during the peak time at 3:00pm when the outside temperature is the hottest (Kharrufa and Adil, 2008). Sharifi and Yamagata did a more comprehensive study and discussed 19 different roof pond systems. These roof ponds were taken from different regions and climate zones. Ponds with movable insulation, shaded ponds, open roof ponds, ventilated roof ponds, energy-roof and walkable roof ponds are examples of some of the roof pond systems that are discussed in this paper. Regardless of the advantages of the roof pond and its effect of reducing the cooling load of the building, some disadvantages were provided in their study. Some of these disadvantages are that roof ponds are not suitable for roofs that are built according to lightweight construction standards because the weight of the ponds need building structures that resist the extra pressure of the ponds, and in case of leaking, this pond system could cause a severe damage to the building's roof, so there should be suitable maintenance (Sharifi and Yamagata, 2015).

\subsection{The Floor System}

The floor system is part of the building envelope which is the flat bottom surface that lay on the ground. The thickness of the floor's insulation layer could increase the annual energy saving as is expounded on D. Aviza and Z. Turski's study (Aviza, and Turskis, 2014). The study shows a comparison of the thickness of the floor's insulation layer is required for the energy performance classes. The energy performance classifies buildings into nine classes from "A++" to " $G$ ". In this classification " $G$ " is the worst technical construction regulation in Lithuania which is the country that the study took place. Buildings are required to have " $\mathrm{C}$ " energy class as a minimum for all newly constructed building. Thus, the study focusses only on the four classes from " $\mathrm{A}++$ " to "C". Results illustrate that a building with " $\mathrm{A}++$ " Class has thermal insulation layer that is four times thicker than the required thickness of "C" class.. Therefore, the building could save a significant amount of energy with just increasing the thickness floor's insulation layer.

\subsection{Insulation System}

The insulation of the building envelope is one of the most decisive factors that contribute to the decrease of cooling loads of houses in hot-dry regions. The type of insulation material used depends on the market availability, climate, and the required level of insulation that a building needs. The insulation materials are the most effective element of the envelope that can increase the thermal resistance (R-value). Al-Sanea and his colleagues did a study of the three most common insulation materials and installed them in two different masonry materials which are hollow concrete block and hollow red-clay block. One of the remarkable results that they found was that "R-value of wall under optimum conditions becomes more dominated by insulation type rather than by masonry type" (Al-Sanea, Zedan, Al-Mujahid and Al-Suhaibani, 2016).

An important aspect in achieving better insulation performance is the number and location of insulation layers. The study that has been done by Al-Sanea and Zedan compared between different wall configurations and the effect of the number and location of the insulation layers in the wall. All investigated walls had the same thermal mass, which is $308 \mathrm{~mm}$. Additionally, they had the same materials, which were $15 \mathrm{~mm}$ thick cement plaster on each side enclosing the wall assembly, either 100 or $200 \mathrm{~mm}$ thick, heavyweight hollow concrete blocks (HWHCB), and molded polystyrene for the insulation layers. The climate condition used in this study was that of Riyadh, Saudi Arabia which is a hot-dry region. The results showed that the best thermal performance was achieved by wall $\mathrm{W} 3$ which had three layers of insulation, each $26 \mathrm{~mm}$ thick, then wall $\mathrm{W} 2 \mathrm{c}$ that had two layers of insulation with $39 \mathrm{~mm}$ thickness in each one, placed on the outside and in the middle of the wall. The least thermal performance was wall $\mathrm{W} 1$ that had one $78 \mathrm{~mm}$ insulation layer placed inside. (Al-Sanea and Zedan, 2011). 


\subsection{Fenestration System}

The definition of the fenestration system is "a non-load-bearing element that is installed within a wall" (American, 2014). The components of a fenestration system include windows, doors, curtain walls, louvers, skylight and clerestories. Energy consumption is highly influenced by fenestration systems throughout the infrastructure. When constructing a fenestration system, the elements that should be most considered are, the heat transfer coefficient (U-value), solar heat gain coefficient (SHGC), light-to-solar gain (LSG), and visible light transmittance(VLT). To expound, the U-value is the rate of the heat transmission through the fenestration materials and it is expressed in units of Btu/hr- $\mathrm{ft}^{2}-{ }^{\circ} \mathrm{F}$. Materials with lower U-value are more insulated and energy-efficient. The SHGC quantifies how much solar heat passes into the building through the glass. The measurement rate of SHGC is from 0 to 1 , with zero indicating $100 \%$ of solar heat is blocked, and one meaning the glass allows $100 \%$ of the solar heat to pass through. The LSG is the ratio between SHGC and visible light transmittance(VLT). A higher number of LSG means the glass transmits more light with fewer amounts of heat (U.S. Department of Energy).

Ajla Aksamija mentioned in her book an essential metric of an envelope's characteristic which is the window-to-wall ratio (WWR); in other words, it is the ratio of glazing area to opaque component area (Aksamija, 2013). She showed the relationship between WWR and the energy consumption and solar heat gain for north oriented office spaces in different locations throughout the United States. The study shows that in the BWh regions, having a smaller WWR is more advantageous because windows increase the solar heat gain, resulting in more cooling loads required for the building (Aksamija, 2013).

\subsection{Orientation}

Another critical design strategy with various ramifications on the building envelope is building orientation. The amount of solar radiation that the building envelope receives changes from one season to another due to the changing of the sun's position and angle in the sky. The orientation of the building is a leading factor in the decrease or increase of the amount of solar radiation that horizontal and vertical walls, as well as the inclined roof, can gain. In most climate zones, the primary purpose of the orientation is to maximize the building envelope's solar exposure in winter and to minimize it in summer. The walls that are exposed to the highest solar radiation in summer are the ones located in the east and west facades, where they get the lowest solar radiation in winter as well. The southern walls, especially in the northern hemisphere, receive the highest solar intensity in winter and summer they intake low solar radiation (Givoni, 1998).

One of the most informative studies about building orientation was done by Faizi, Noorani, Ghaedi and Mahdavinejad, named the Case Study of Maskan Mehr Complexes in Tehran, Iran. It focused on four features of the building which are building orientation, overall size, a form of building, and translucent layers and the thermal inertia of layers. Then, the study analyzed four different types of buildings in Maskan Mehr complexes, gathering data on shadows and overshadowing, solar radiation, lighting access simulation, and thermal simulation and analysis. These analyses show varied results between the four residential building types (Faizi, Noorani, Ghaedi and Mahdavinejad, 2011). Many Other studies have also discussed the optimum orientation of the building such as Morrissey, Moore and Horne (2011), Givoni (1998) and Aksamija (2013). These studies show that choosing the right orientation of a building reduces a considerable amount of energy consumption, especially in very extreme climates like in the desert regions. Each of these studies suggests that in hot-dry regions a building's long axis should be oriented to the east-west axis to maximize the northern and southern facade area (Morrissey, Moore and Horne, 2011) (Givoni, 1998) (Aksamija, 2013).

\subsection{Courtyard}

A very practical facet of design is building form, especially when dealing with hot-dry climates. In the study done by Manioğlu and Oral, they state that the courtyard shape has a significant effect on heating and cooling the building in the hot and dry climate. The geometric shape of the courtyard significantly impacts the shadows produced on the building envelope and the amount of solar radiation that a building receives. This study aims to show simulations of different shapes of courtyards and building envelopes in Diyarbakır, Turkey, a hot-dry region. The determination of building form (courtyard building) alternatives and the decision of the building envelope were the only factors that these studies addressed. The results of this study illustrated that by increasing the floor area of the courtyard, the cooling and heating loads of the building gradually increase. Many details in this research reveal how a small change in the design can make a substantial difference. This study is an example of the efficacy of the courtyard design for reducing the energy demands (Manioğlu \& Oral, 2015).

Another study done by Muhaisen (2006) assessed the shading performance of courtyard forms to provide the maximum amounts of shadow in summer and sunlit areas in winter. The study examined various locations, one 
being Cairo, Egypt which is a hot-dry region. Many aspects of the courtyard design were discussed in this study. Firstly, the percentage of the shaded internal wall surface area of the courtyard which reduces gradually whenever the courtyard becomes shallower; however, in winter, when a courtyard is less deep, a more sunlit area will be obtained. Second, the orientation of the courtyard and the results show that in a hot dry climate, the optimum orientation to ensure an efficient performance in both summer and winter is that which places the courtyard between the northeast-southwest axis and the north-south axis. Finally, the most appropriate courtyard height and a number of stories that can be obtained in a hot-dry region in both seasons was found to be two stories (Muhaisen, 2006).

\section{Methodology}

\subsection{An Overview}

The premise of this research is about the efficiency of the building envelope's design and how it can contribute to achieving net-zero energy for single family homes in hot-dry climate regions. The investigation includes the selection of the most appropriate building envelope materials, some design strategies that optimize the building envelope's efficiency, determining the sufficient insulation for the whole envelope, solving challenges associated with hot-dry climate, and the installation of the proper photovoltaic type and number. The sampling design is those families who live in the hot- dry regions and are willing to build a net-zero energy house. The research uses data from different sources. These sources include:

\subsection{The Previous Methods}

One of the most prominent methods of collecting data is by analyzing and gathering information from past studies and literature that are relevant to my current research. A wide variety of research has been done revolving around this particular study area. Every one of these sources focuses on an aspect of my study, so that will be very beneficial as a base for the research. The books and articles that the study relies on are shown in the literature review chapter.

The core parts of this research such as the building envelope's materials, fenestration insulation, and solar energy types require the newest materials to get the best results. This data can be obtained from conferences and exhibitions that showcase the cutting-edge technologies and innovations to date. The AIA Conference on Architecture 2017 is one of the most significant architectural events in the United States, with around 800 leading building product manufacturers showing their architectural products and materials, and a plethora of seminars and workshops. This event gave me a greater understanding of building envelope materials, building envelope design, and fenestration insulation. Another beneficial event that I attended was the California Solar Power Expo. This expo is critical for the research because it showcases the latest technologies of solar power, their efficiencies, and types.

\subsection{Case Studies}

Studying from existing case studies and analyzing them is a beneficial method that supports the research. The case studies that are used are some net-zero energy houses in hot- dry climate regions. Since most of the hot-dry climate regions have almost the same challenges, I targeted just two regions; the first one is a local case study in Phoenix, Arizona, and the other is in Barwa City, Qatar which is in the same climate zone of the proposed design.

\subsection{Analyzing by Using Computer Programme}

The Method is by using computer_simulation programs such as Autodesk Green Building Studio and Insight 360 for Revit.

\subsection{Design Proposal}

The conclusion of this paper is the culmination of all the knowledge gathered and analyzed from literature reviews, case studies, and conferences to put them within arms reach by a proposal design of a single-family home that is net-zero energy in a hot-dry region. The method that was used to test the building envelope performance is by doing energy simulation analysis for two identical house designs; nevertheless, their building envelope designs were different. The first one which is the net-zero energy house that has a high-efficiency building envelope, and the second one which has a traditional building envelope. These simulation software applications aid the study in providing more accurate and reliable results. 


\section{Case Study}

\subsection{Qatar's First Passivhaus}

Qatar's first Passivhaus is located in Barwa City, Qatar. The project is comprised of two houses placed next to each other with an almost identical plan. The first house was constructed to meet the Passivhaus standard and net-zero energy, while the other one was built according to traditional construction practices in Qatar. Both Passivhaus villa (PHV) and the Standard villa (STV) are about $200 \mathrm{~m} 2$ in floor area. The villas are designed for a family of four, consisting of three bedrooms, an open living/kitchen space and a central atrium as is illustrated in Figure 1. In March 2013 the project was completed, and the examination of both houses and their efficiency began (Khalfan and Sharples, 2016).
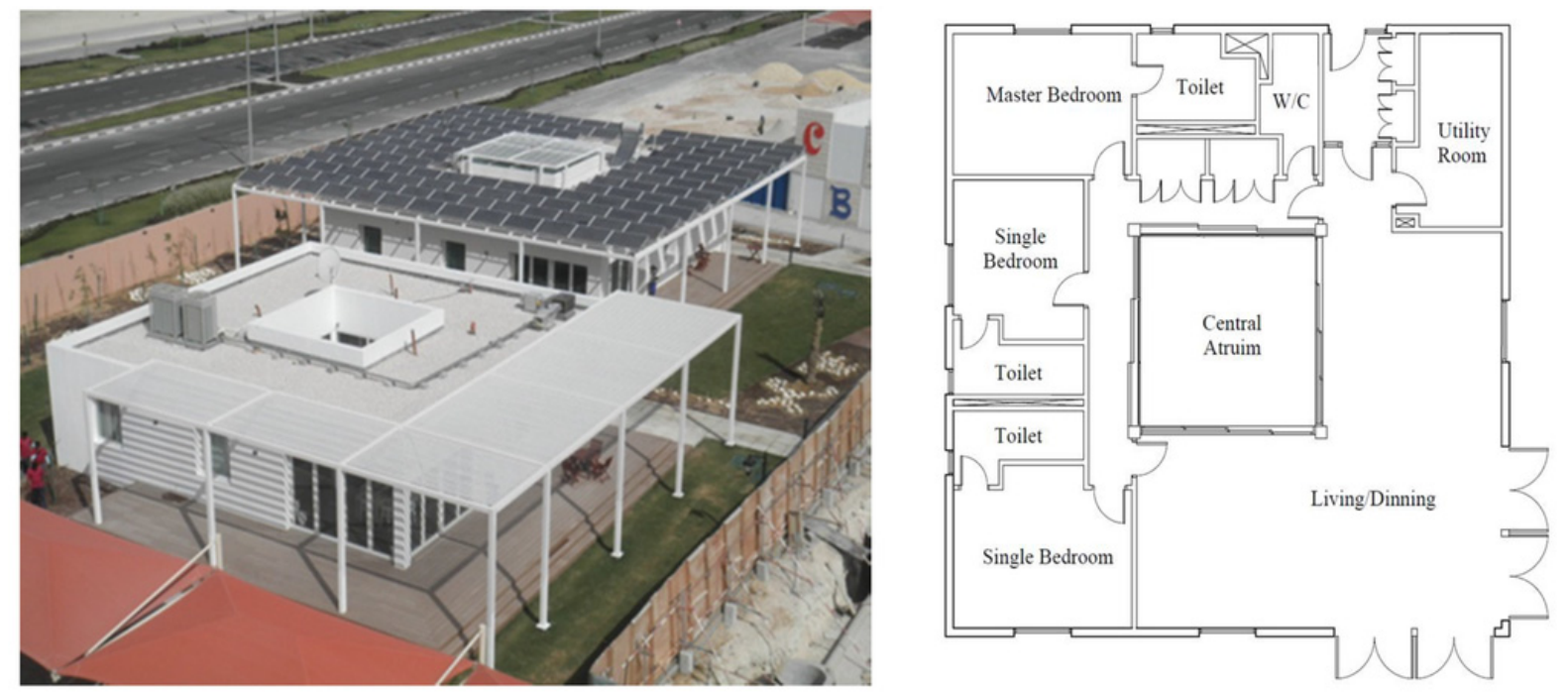

Figure 1. PHV and STV perspective and layout (Khalfan and Sharples, 2016)

Although the layout of both villas is practically the same, their building envelope materials and components are different. The PHV is entirely insulated, with minimal air leakages and thermal bridges. Table 1 shows both the PHV and STV building envelope materials and table 2 shows the U-value for each component of the building envelope. The building envelope design was not the only factor that was taken into account in the PHV, but other aspects have been considered. These include the high efficiency cooling system and heat recovery ventilation unit, solar water heating, high energy efficient lighting system, a $220 \mathrm{~m} 2$ photovoltaic array installed on its roof, and a grey water system (Khalfan and Sharples, 2016).

Table 1. PHV and STV building envelope materials (adapted from Khalfan and Sharples, 2016)

\begin{tabular}{|c|c|c|}
\hline Construction & PHV & STV \\
\hline Wall & $\begin{array}{l}200 \mathrm{~mm} \text { block work }+380 \mathrm{~mm} \\
\text { Polystyrene layer }\end{array}$ & $\begin{array}{l}300 \mathrm{~mm} \text { block work }+50 \mathrm{~mm} \\
\text { cavity in between }\end{array}$ \\
\hline Roof & $\begin{array}{l}200 \mathrm{~mm} \text { Cast concrete }+380 \mathrm{~mm} \\
\text { Polystyrene layer }\end{array}$ & $\begin{array}{l}200 \mathrm{~mm} \text { Cast concrete }+100 \mathrm{~mm} \\
\text { Polystyrene layer }\end{array}$ \\
\hline Floor & $\begin{array}{l}250 \mathrm{~mm} \text { Cast concrete }+200 \mathrm{~mm} \\
\text { Polyfoam layer }\end{array}$ & $250 \mathrm{~mm}$ Cast concrete \\
\hline Glazed Surfaces & $\begin{array}{l}\text { Triple glazing-6 } \mathrm{mm} \text { clear and } \\
\text { coated glass - double } 12 \mathrm{~mm} \text { cavity }\end{array}$ & $\begin{array}{l}\text { Double glazing - } 6 \mathrm{~mm} \text { clear float } \\
\text { glass - single } 12 \mathrm{~mm} \text { cavity }\end{array}$ \\
\hline
\end{tabular}


Table 2. PHV and STV U-values (W/m2K) (adapted from Khalfan and Sharples, 2016)

\begin{tabular}{llll} 
Construction & PHV & STV & Passivhaus Requirement \\
\hline Walls & 0.084 & 1.31 & $0.10-0.15$ \\
Roof & 0.084 & 0.30 & $0.10-0.15$ \\
Floor & 0.11 & 0.50 & $0.10-0.15$ \\
Glazed surfaces & 1.11 & 2.61 & 0.85 \\
\hline
\end{tabular}

The study shows that the insulated PHV consumes much less energy than STV. The simulated results indicate that the PHV would consume approximately half of the amount of energy that STV used; notwithstanding, the actual measurement illustrated that the PHV is using just about a third of the energy used in the STV as is depicted in Figure 2. The energy consumption of the PHV is around half of the energy generated by the 400 $\mathrm{kWh} / \mathrm{m} 2 \mathrm{PV}$ system as is shown in Figure 3 (Khalfan and Sharples, 2016).

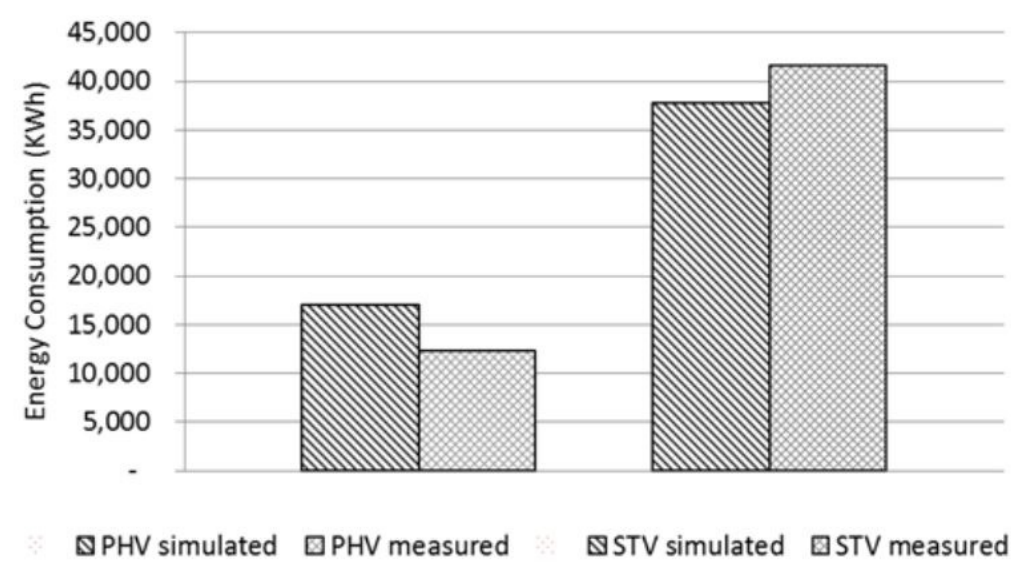

Figure 2. PHV and STV energy consumption

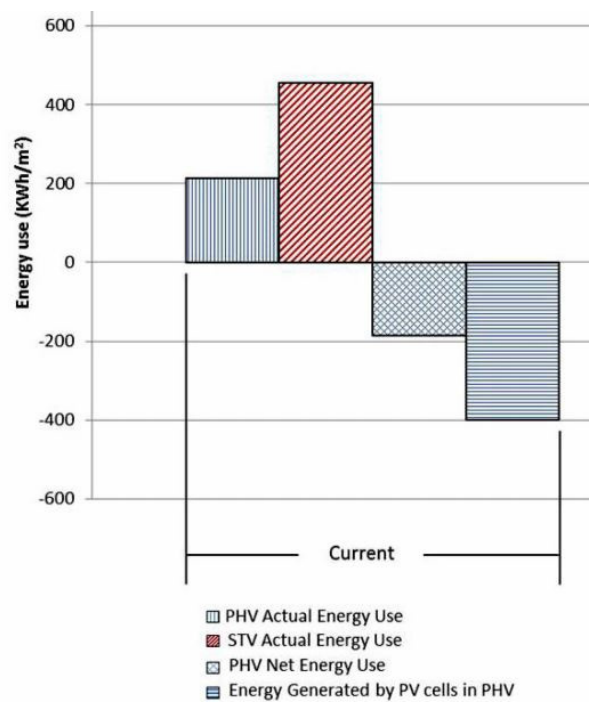

Figure 3. Energy generated by PV (Khalfan and Sharples, 2016)

The results of this study showed remarkable evidence of how the well-designed building envelope can make a significant reduction in the cooling energy load, which is the most dominant factor in energy consumption of a house in hot-dry regions. Qatar's climate is very similar to most parts of Saudi Arabia. Thus all the design strategies that were used in this PHV can be applied for a house in Saudi Arabia. Other lessons that can be learned from this case study include the efficiency of wall, roof and floor insulation materials and the 
fenestration system design that is used in the PHV.

\section{Design Proposal}

The design proposal is for a single-family home in Riyadh, Saudi Arabia that is considered as a very hot-dry region (BWh) based on the Koppen Climate Classification. The strategies implemented in the design of this home have been selected and adapted from all the research, books and case studies that are mentioned in both chapters 2 and 3. The design shows the powerful effect of the building envelope in decreasing the energy consumption of the house compared to a traditional building envelope design. The process followed to create this design proposal was first to analyze the site's climate and condition. Second, by taking into consideration the standard of Saudi single-family home design as a baseline. Third, by applying the building envelope design strategies that were learned from the former studies. Fourth, by making energy simulations and energy analyses to estimate the potential energy consumption. Finally, by installing sufficient photovoltaics that generates as much energy as the house consumes, to achieve a net-zero energy home; successfully designing a net-zero energy home is the study goal.

\subsection{Site Analysis}

The site is located in Al-Malqa, Riyadh, Saudi Arabia which is in the northeastern part of Riyadh- the capital of Saudi Arabia. The site is served by all services such as electricity, water and sewage system as in most residential neighborhoods in Riyadh. The primary reason for choosing this location among other sites in Riyadh is due to its long axis oriented to the north-south axis. Thus, this design proposal can accommodate many sites within Riyadh, and even any site throughout the globe that is in a hot dry region.

The climate of Riyadh is very hot-dry in the summer and cold in winter. The summer season is in April, May, June, July, August, September and October while the warmest month is August. However, from November until March Riyadh has pleasant, cold weather and becomes the coldest in January. Most precipitation is seen in April and usually does not exceed $25 \mathrm{~mm}$ as is shown in Figure 4 (Meteoblue). The humidity in Riyadh is generally low and does not exceed 55\% as is seen in January, illustrated in Figure 5 (Weather and Climate).

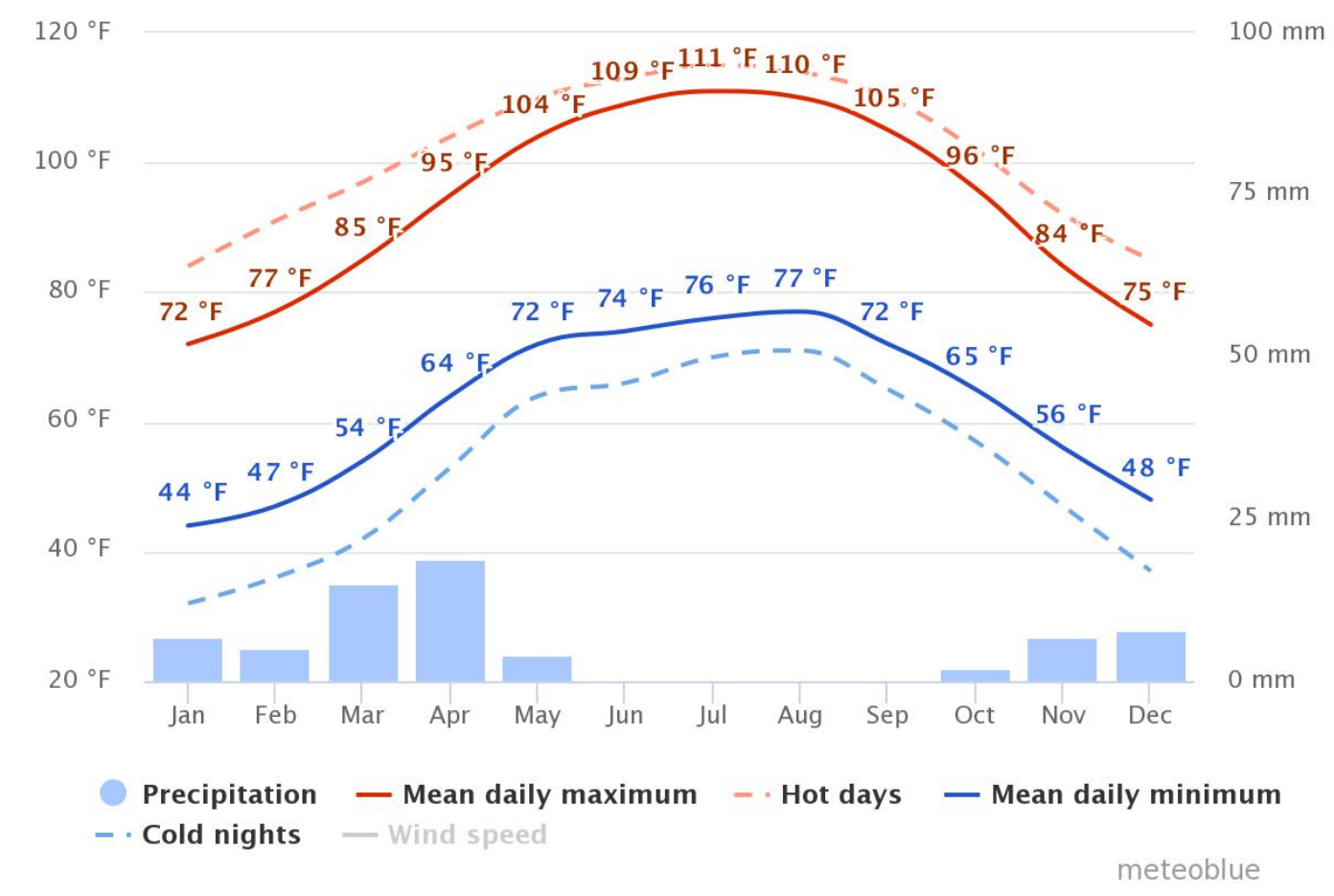

Figure 4. Average temperatures and precipitation (Meteoblue) 


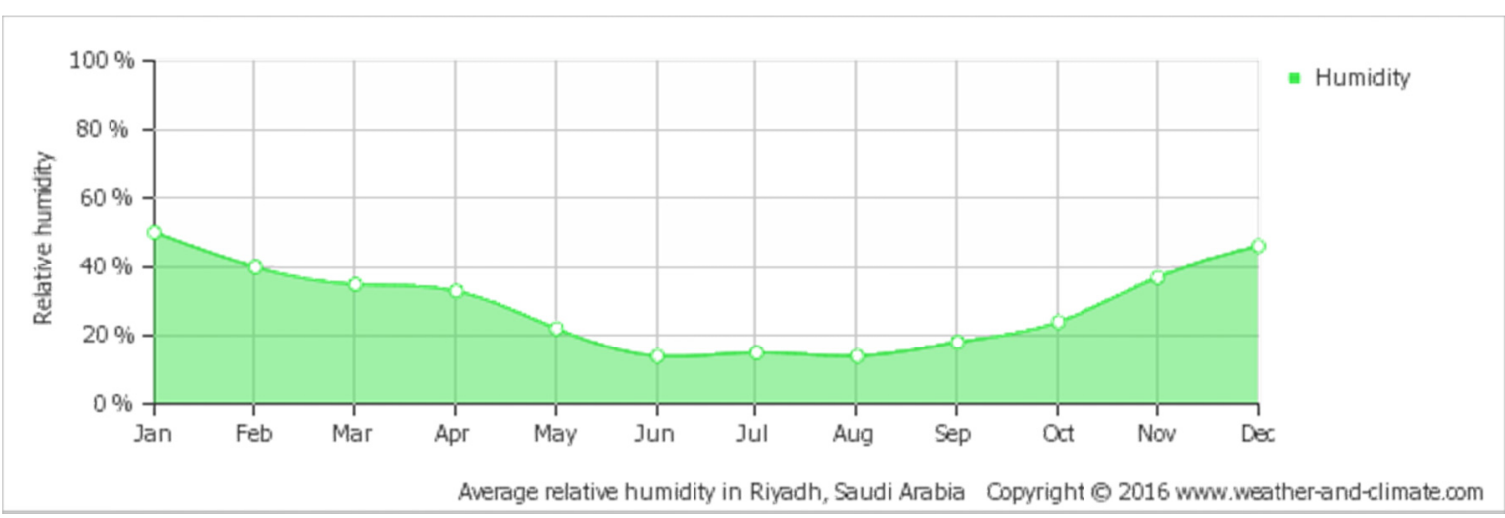

Figure 5. Average relative humidity (Weather and Climate)

Riyadh also has clear skies for most of the year. Annually, Riyadh has around 277 sunny days. Additionally, there are about 63 partly cloudy days which leave only about 25 overcast and rainy days as is displayed in Figure 6 (Meteoblue). With only around 25 cloudy days a year, the chance of generating a lot of energy by photovoltaics can be significantly more than most places around the world.

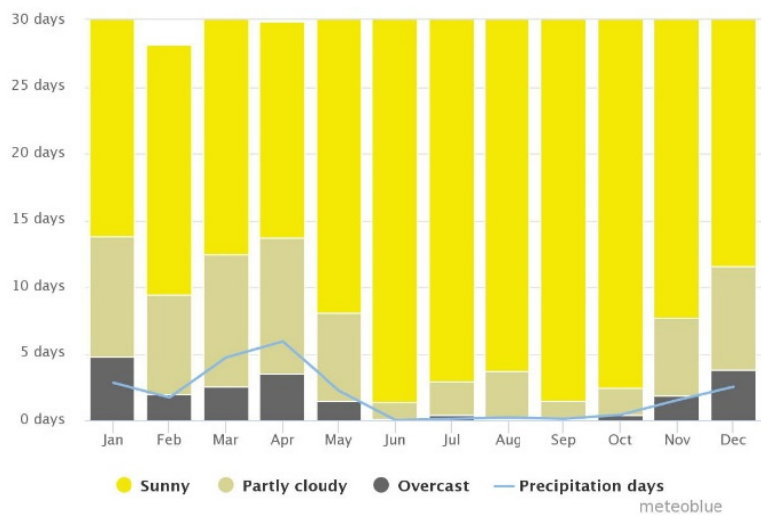

Figure 6. Average cloudy, sunny, and precipitation days for each month (Meteoblue)

\subsection{The Design General Information}

The house is for a Saudi family of six members. There are two stories, and the gross floor area is $4142 \mathrm{ft} 2$ (384 $\mathrm{m} 2$ ). The form of the house is almost rectangular with its long axis oriented to the East-West axis, with an $18 \mathrm{x}$ $13 \mathrm{ft}$. Courtyard that is centrally located. The first floor includes two entrances, one for guests and the other for the residents, two large guest rooms each with a bathroom, a kitchen and dining room. The second floor has the master bedroom and bath, two bedrooms that have private bathrooms and one additional bedroom that shares a bathroom with the living room as displayed in Figure 7-9. 


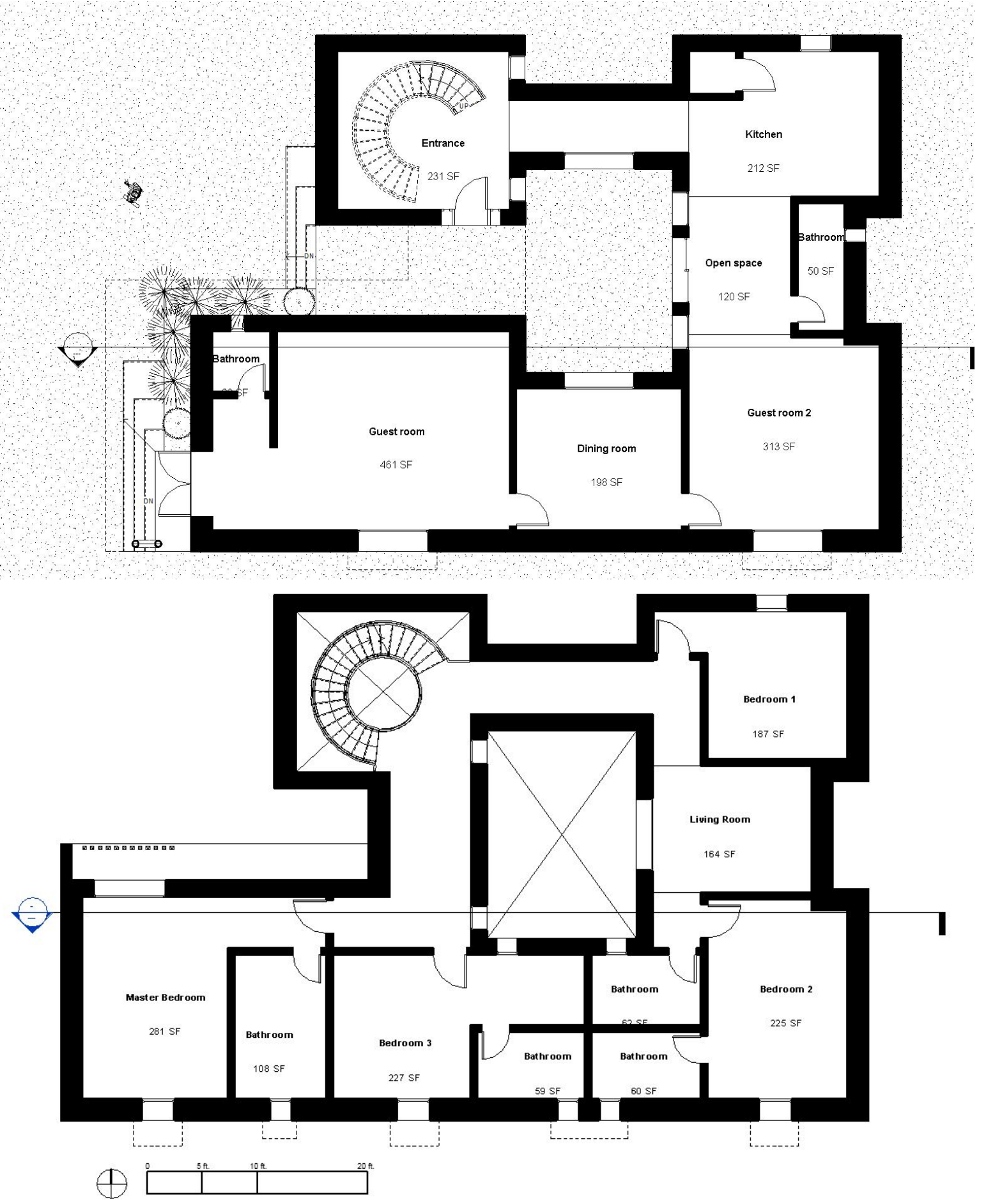

Figure 7-8. Proposed design first and second floors 

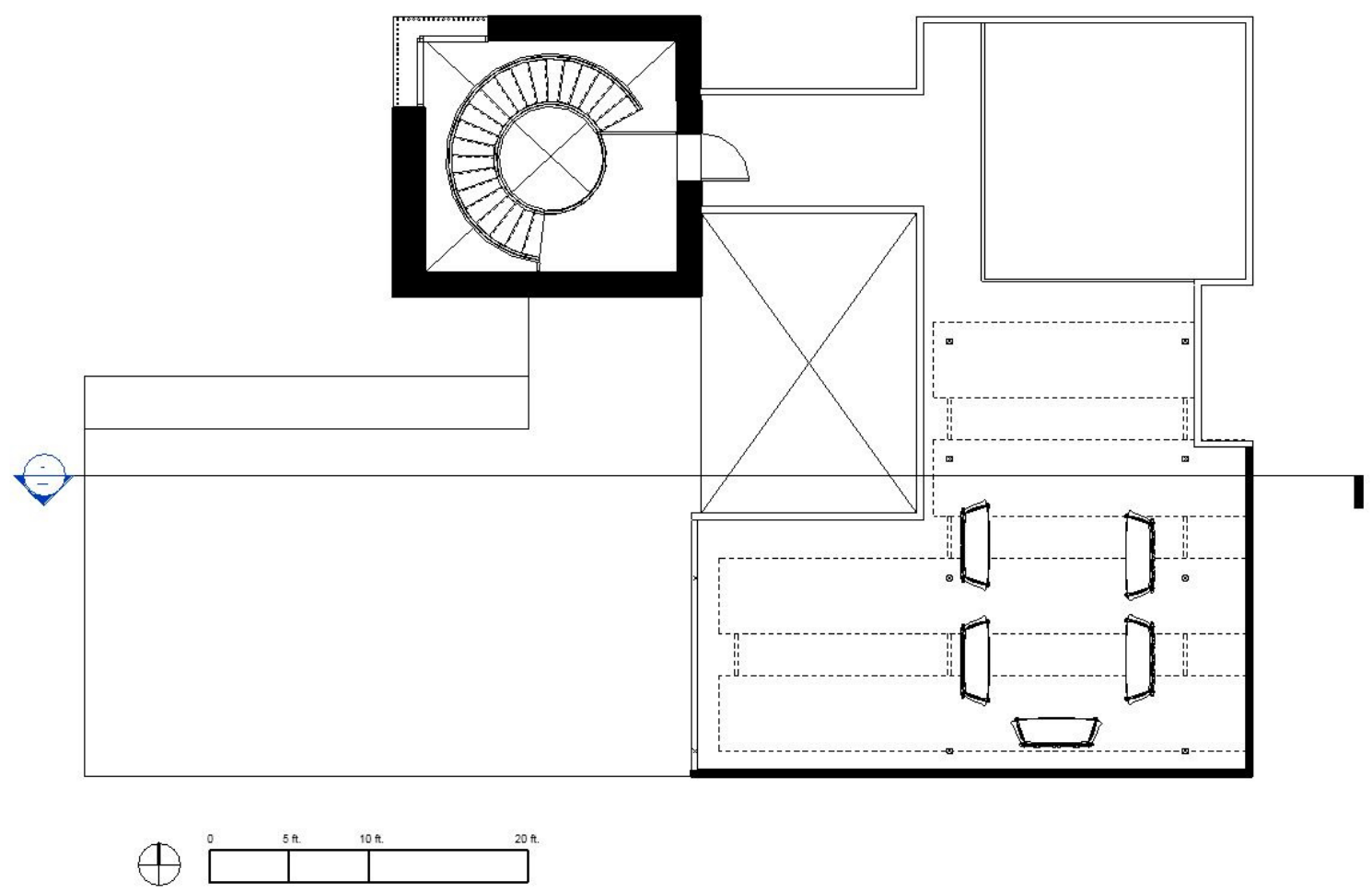

Figure 9. Proposed design third floor (house's roof)

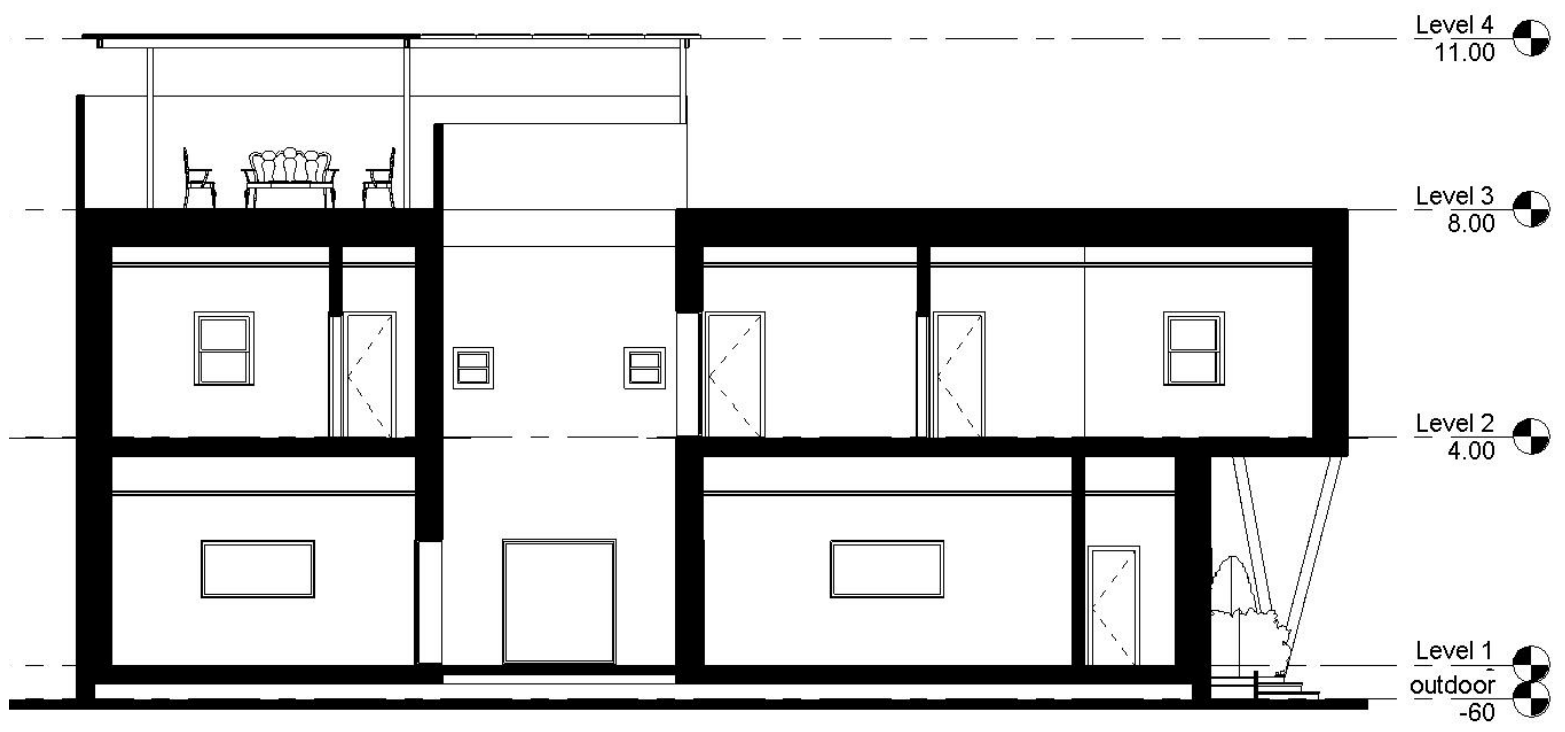

Figure 10. The house's section 


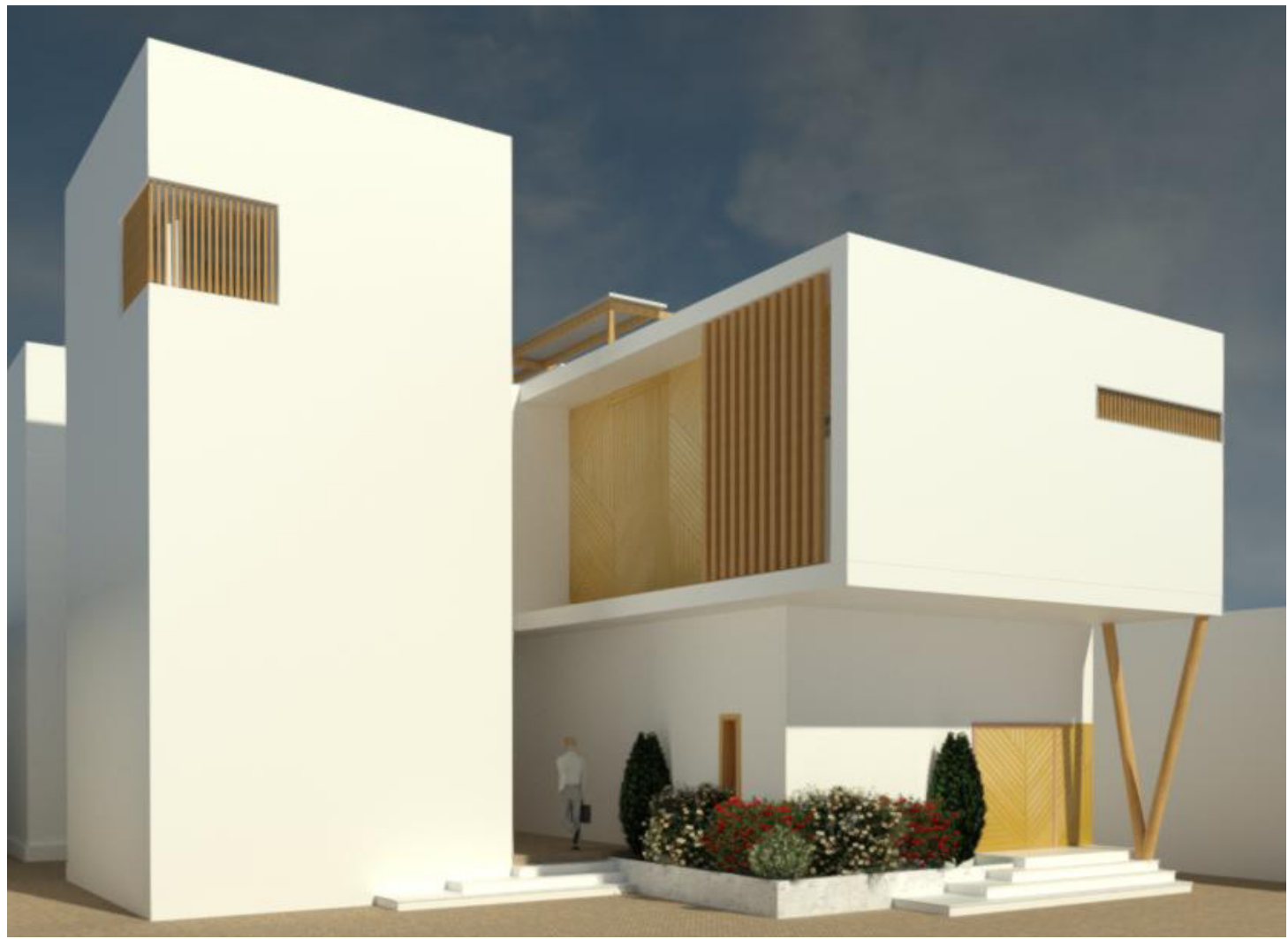

Figure 11. Perspectives of the house

\section{Discussion and Results}

\subsection{Design Strategies}

Many strategies have been utilized to make this home a net-zero energy building. The form of the house, orientation, the courtyard, the wall and roof systems, the insulation and fenestration system all contribute to achieving the optimal design of the building envelope.

\subsection{The House Layout}

The shape of the floor plan is almost rectangular, and the long axis is on the east-west axis to maximize the southern and northern facade areas. This orientation is prime due to both the south and north facades receiving the least solar radiation, as expounded on in former studies (Morrissey, Moore and Horne, 2011) (Givoni, 1998) (Aksamija, 2013). The southern wall area is higher than the northern because in winter it receives the highest solar intensity that helps to warm the house and as a result, decrease the heating loads.

The most efficacious characteristic of the layout is the courtyard. The 18 x $13 \mathrm{ft}$. Rectangular courtyard is located centrally. The length lies on the north-south axis. This orientation of the courtyard maximizes the amount of shadow that falls on the courtyard's surrounding envelope in summer, and the sunlit area in winter (Muhaisen, 2006). The courtyard is not entirely closed from all sides, as it has an $8.3 \mathrm{ft}$. wide corridor on the first floor. This corridor, displayed in Figure 12, allows the prevailing winds that blow from the southeast (as is illustrated in Figure 13, to flow through, cooling down the courtyard and providing ventilation. Consequently, heat gains of the courtyard's envelope are largely minimized. 


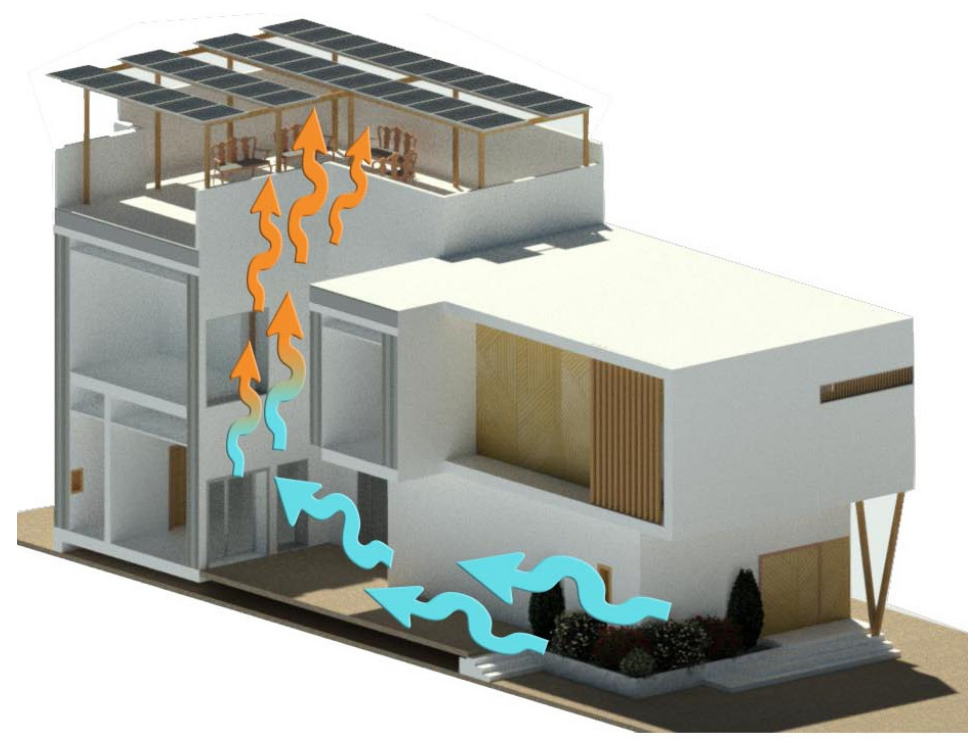

Figure 12. Air movement

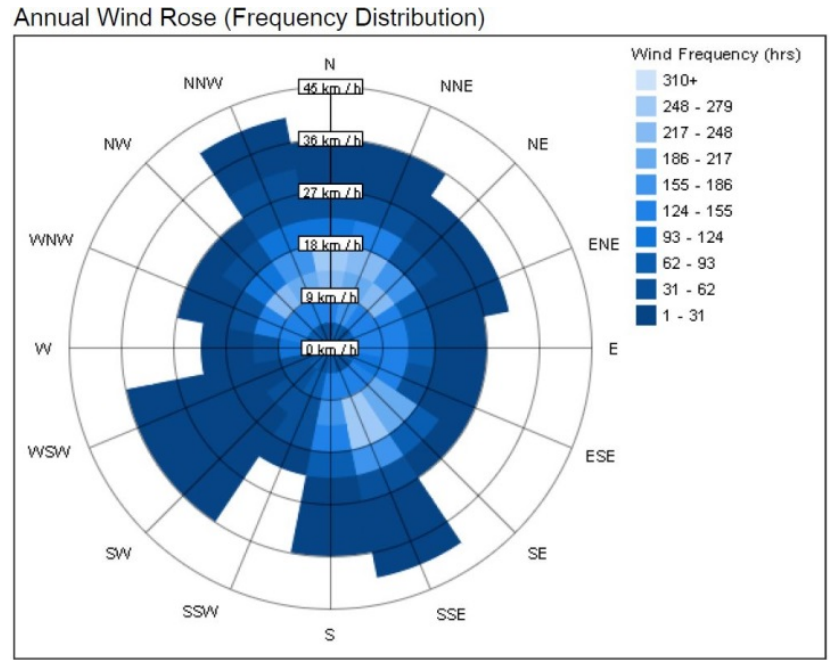

Figure 13. Wind rose for Riyadh, Saudi Arabia (Revit analysis)

\subsection{Wall System}

The exterior walls are highly insulated and are one of two different sizes and configurations depending on their location. The thick walls can be seen in the East, West and South facades as is displayed in the plans in Figures 7-9. The reason behind this placement is because those facades get direct solar radiation; however, the thinner walls are in the northern façade and are also surrounding the courtyard because they are shaded for most of the day. The thicker wall configuration has half an inch thick cement plaster in each side enclosing the wall assembly, two arrays of heavyweight hollow concrete block (HWHCB) each one 6 inches thick, and two layers of expanded polystyrene insulation, each 6 inches thick, and placed on the outside and in the middle of the wall. The thinner walls have the same elements but differ in one insulation layer versus two, as shown in Figure 14. The reason for choosing the heavyweight hollow concrete block (HWHCB) and the reinforcement concrete for the structural system is due to them being the most common construction systems that are used for residential buildings, and most buildings throughout Saudi Arabia. Regarding the expanded polystyrene insulation, there are several reasons for its selection. Reasons include its availability, and affordability compared to its efficiency, the variety of sizes to choose from, and its high rating of performance according to Qatar's first Passivhaus case study. The total R-value of the thick walls is $51.5 \mathrm{~h}-\mathrm{ft} 2-\mathrm{oF} / \mathrm{Btu}$, while the smaller one is $27.5 \mathrm{~h}-\mathrm{ft} 2-\mathrm{oF} / \mathrm{Btu}$ as is 
illustrated in Appendices A and B (Colorado energy, 2016) (Aksamija, 2013).

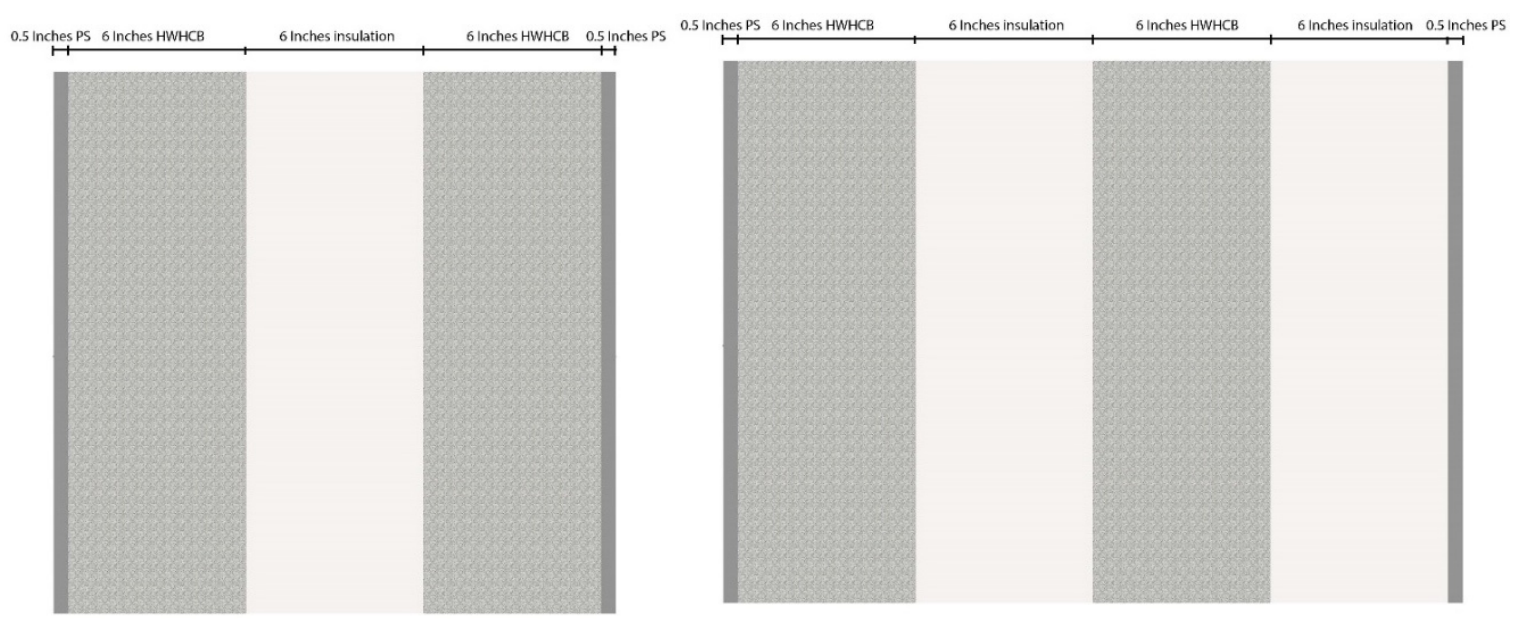

Figure 14. Walls section

\subsection{Roof System}

Roofs have the highest exposure to solar radiation on any given structure, necessitating strategies to decrease heat gain in homes. In optimizing the roof performance, its element configuration plays a leading role. The roof shape resembles that which is used in Qatar's first Passivhaus which was tested and showed a high-performance rating. The second strategy is related to the roof's color; a white roof is used to help reflect the solar radiation and to keep it cooler as is described in Prado and Ferreira's 2005 study. The third one involves the solar panel arrays; they were raised about 8 feet to create a shaded area for outdoor sitting. The photovoltaics array covers around one-third of the roof. Therefore a significant portion of the roof will have an extensive shading area, as is illustrated in Figure 15. Finally, the roof pond strategy can be seen in the back area that is uncovered to make the sitting area aesthetically pleasing, as well as to reduce the roof temperature as is shown in Figure 15. The depth of the pond is just 0.5 inches in order to avoid adding unnecessary weight to the structure. 


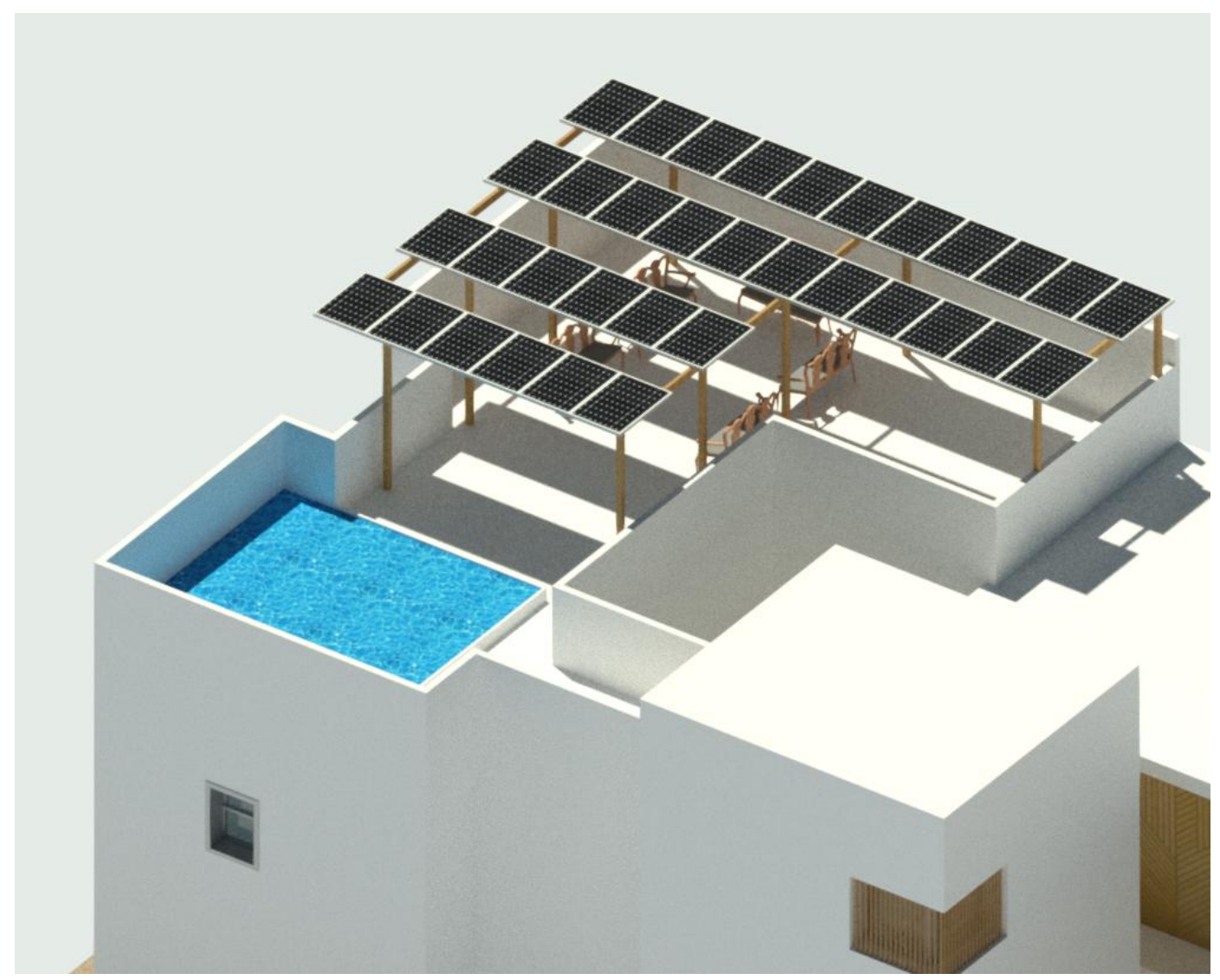

Figure 15. The house's roof perspective

\subsection{Fenestration System}

The fenestration system in this house can be seen in windows, doors and shading devices. Windows are the most critical and active element of the fenestration system, so they were placed in very appropriate positions. As is illustrated in the plans, there are no windows in both the East and West facades. The decision to forsake windows in the design of the eastern and western facades is due to their exposure to extremely high amounts of solar radiation in summer and their lack of exposure to solar radiation in winter. Although there are no windows in these facades, the sunlight still permeates and reaches inside the home. The reason is that most of the house's windows are opened to the courtyard. The windows in the courtyard can receive natural light without direct sunbeams. Almost all bedrooms except the smallest one have windows in the southern façade because in winter they receive the highest solar intensity that reduces the heating loads. All these windows that are located on the south façade have a horizontal shading device to protect them from the direct sunbeams. The glazed surface that is used is the double pane clear - high performance, LowE with a U-value of around $0.37 \mathrm{BTU} /\left(\mathrm{h}^{\circ} \mathrm{F} \mathrm{ft} \mathrm{ft}^{2}\right)$ and its $\mathrm{R}$-value at $2.7 \mathrm{hr} \cdot \mathrm{ft} 2 \cdot{ }^{\circ} \mathrm{F} / \mathrm{Btu}$ as is illustrated in Table 3. Further, seeing that the walls are thick, a valuable technique is to, place the glazed surface inside the wall casts a shadow on the window pane, as is illustrated in Figure 16. 
Table 3. U-value and R-value of windows (Autodesk ${ }^{\circledR}$ Sustainability Workshop)

\begin{tabular}{|c|c|c|c|c|}
\hline \multirow[t]{2}{*}{ Construction type } & \multicolumn{2}{|c|}{ U-value } & \multicolumn{2}{|c|}{ R-value } \\
\hline & $\mathrm{W} / \mathrm{m}^{\wedge} 2 \bullet \mathrm{K}$ & $\mathrm{BTU} /\left(\mathrm{h}^{\circ} \mathrm{F} \mathrm{ft}^{2}\right)$ & $m^{\wedge} 2 \bullet k / W$ & $\mathrm{~h}^{\circ} \mathrm{Fft}^{2} / \mathrm{BTU}$ \\
\hline Single pane & 4.8 & 0.85 & 0.21 & 1.2 \\
\hline $\begin{array}{r}\text { Double pane, } \\
\text { air filled }\end{array}$ & 2.8 & 0.49 & 0.36 & 2.0 \\
\hline $\begin{array}{r}\text { Double pane, } \\
\text { low-E }\end{array}$ & 2.1 & 0.37 & 0.48 & 2.7 \\
\hline $\begin{array}{r}\text { Double pane, low-E, } \\
\text { Argon filled }\end{array}$ & 1.9 & 0.33 & 0.53 & 3.0 \\
\hline Triple pane & 2.1 & 0.37 & 0.48 & 2.7 \\
\hline $\begin{array}{r}\text { Triple pane, } \\
\text { low-E, Argon filled }\end{array}$ & 1.4 & 0.25 & 0.71 & 4.1 \\
\hline $\begin{array}{r}\text { Quadruple pane, } \\
\text { very low-E, Krypton filled }\end{array}$ & 0.74 & 0.13 & 1.35 & 7.7 \\
\hline $\begin{array}{r}\text { Quintuple pane, } \\
\text { very low-E, Xenon filled }\end{array}$ & 0.51 & 0.09 & 1.96 & 11.1 \\
\hline
\end{tabular}

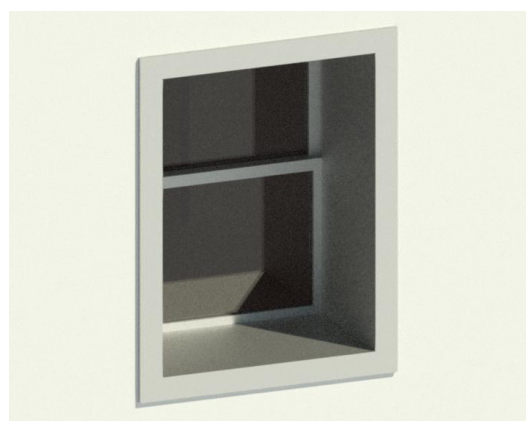

Figure 16. The window frame

\subsection{Energy Simulation Analysis of the Proposed Design}

The energy simulation tool is potent in estimating the energy consumption of the house and provide a clear vision of the envelope performance. Despite the fact that the results are not very accurate and do not examine every design strategies, it can at least help to compare among different design strategies and show which are the most advantageous and efficient. The simulation programs used to obtain these results are Autodesk Green Building Studio and Insight 360 for Revit.

The results indicate that the total energy consumption of the building is $19,127 \mathrm{kWh}$ if the entire house works 12 hours every day for the whole year. It should be noted that all spaces working for 12 hours is more than what the actual consumption will be, especially since there are some spaces like most of the first floor that are used maybe one time per month or even less. But to expect more energy consumption while in the design phase is better than the alternative to install the sufficient solar panels. Around $64 \%$ of the annual energy use will be for the HVAC which is $12,219 \mathrm{kWh}, 18 \%$ for the lighting, and $18 \%$ for miscellaneous equipment as is displayed in Figure 17. The dominant energy use is for the space cooling with about $36.6 \%$ of the total energy consumption. The energy consumption is varied each month, but the peak happens in August. In general, the summer months May, June, July and August as is displayed in Figures 18-19, have approximately double the energy consumption rate than the winter months December, January and February; the house consumes the least energy in December. 


\section{Annual Electric End Use}

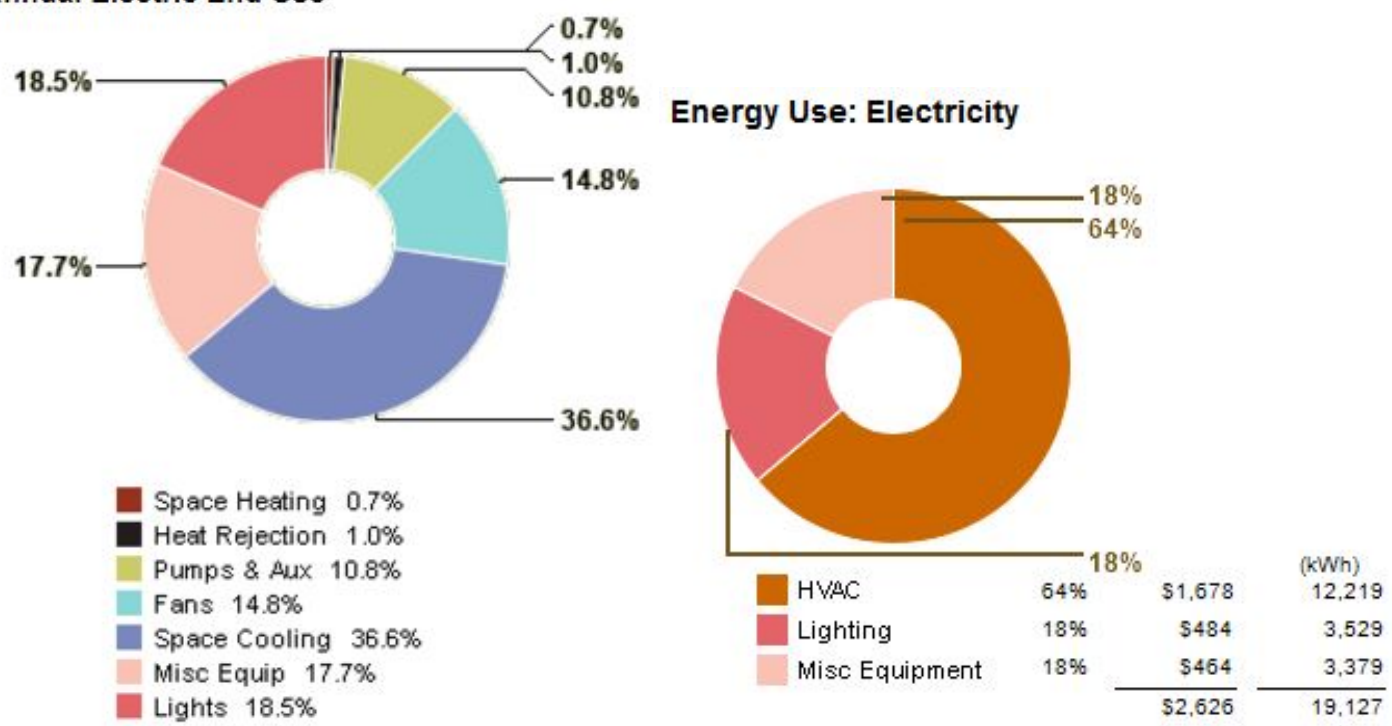

Figure 17. The total energy consumption

\section{Monthly Electricity Consumption}

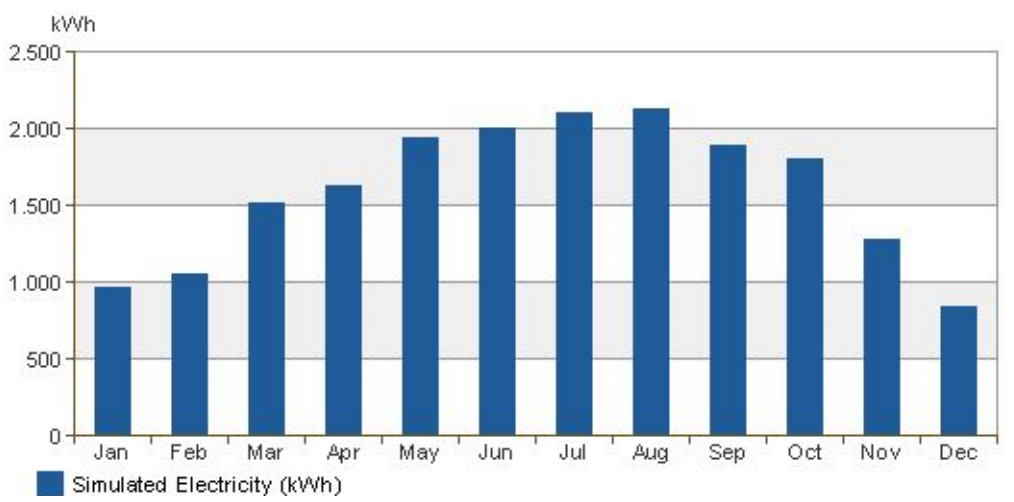

Figure 18. The monthly energy consumption (by Autodesk Revit)

\section{Monthly Peak Demand}

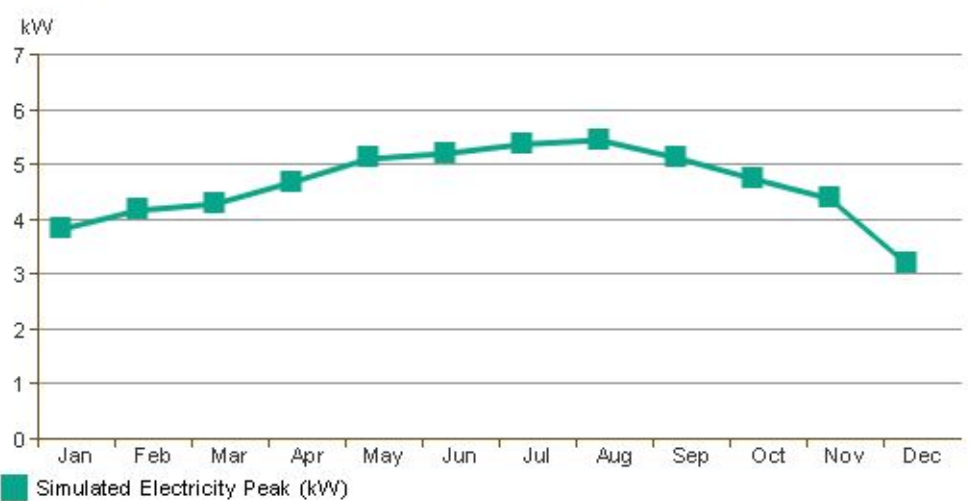

Figure 19. The monthly peak demand 


\subsection{Energy Simulation Analysis of a Traditional Design}

The traditional design that is used is identical to the house's plan and form, but with a less efficient building envelope design. The wall and roof systems that are used are common in Saudi houses, which are HWHCB for walls and the reinforcement concrete for the structural system, but without insulation. The glazing type for all windows is the single pane, with no shading devices for the southern windows. Additionally, the walls and roof color is dark and not reflective.

The simulation results showed a significant increase in energy consumption. The total energy consumption is $36,942 \mathrm{kWh}$. All the extra energy is attributable to the rise of the cooling loads as is illustrated in Figure 20. The gap between the summer and winter consumption increased, which made the December energy consumption almost one-third of the August energy use due to the drastic increase in the cooling demand as is shown in Figure 21.
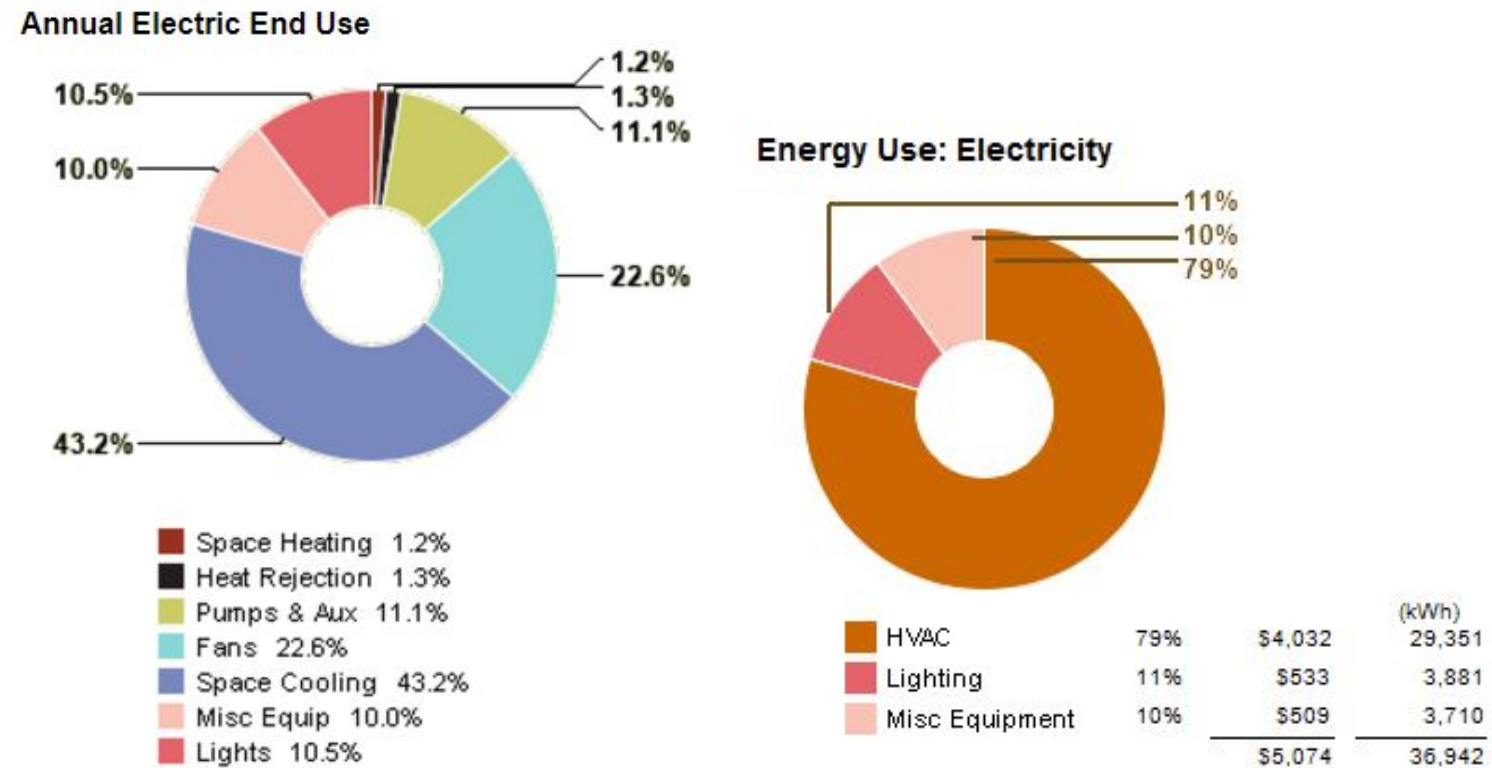

Figure 20. The total energy consumption

\section{Monthly Electricity Consumption}

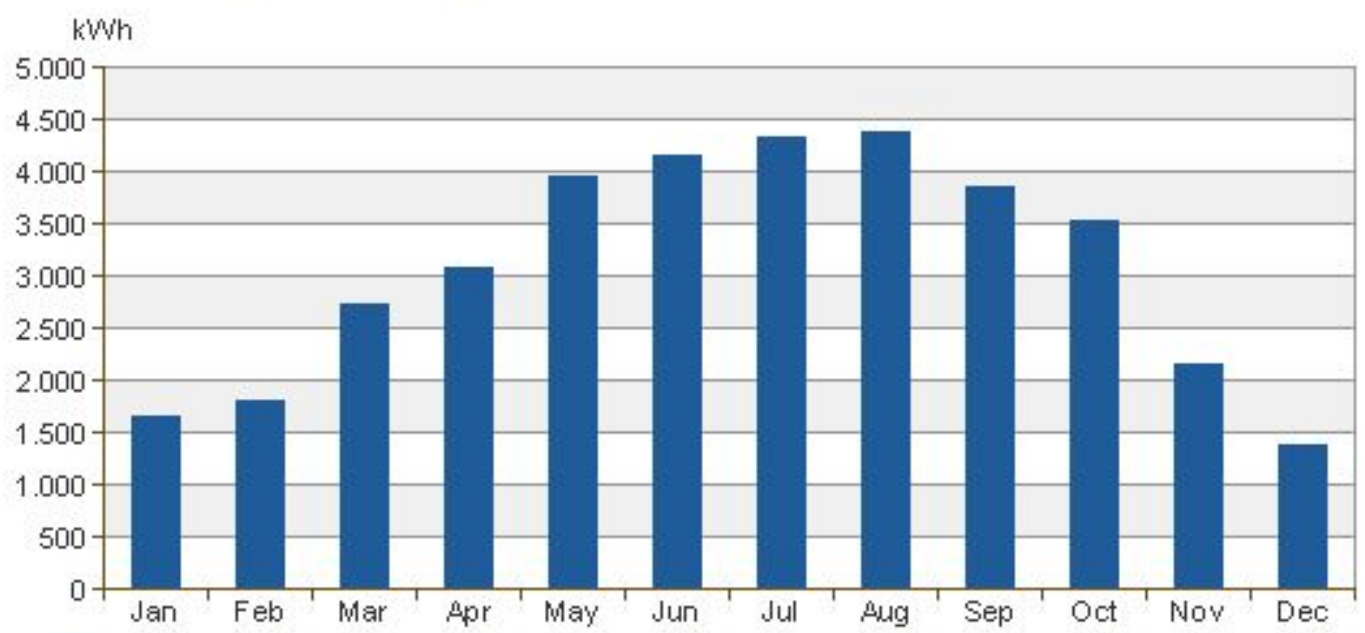

Simulated Electricity ( $k$ Wh)

Figure 21 . The monthly energy consumption 


\subsection{Energy Simulation Analysis of Each Element of the Building's Envelope}

To determine the most efficient part of the building's envelope, the energy simulation has been undertaken for the design proposal with downgrading the efficiency of each primary system, one by one. First was the wall system, and the results showed that when only this system was changed to the traditional, the total energy consumption dramatically increased by around $10000 \mathrm{kWh}$ per year, as is displayed in Figure 22. The second was the roof system, when stripped of all the strategies, the energy consumption increased about $5000 \mathrm{kWh}$ per year as is shown in Figure 23. Lastly, was the fenestration system efficacy- the results showed that by making all windows a clear single pane, the total energy consumption increased by approximately $3000 \mathrm{kWh}$ per year as is illustrated in Figure 24. Thus, the fenestration system is the least efficient system among the others.

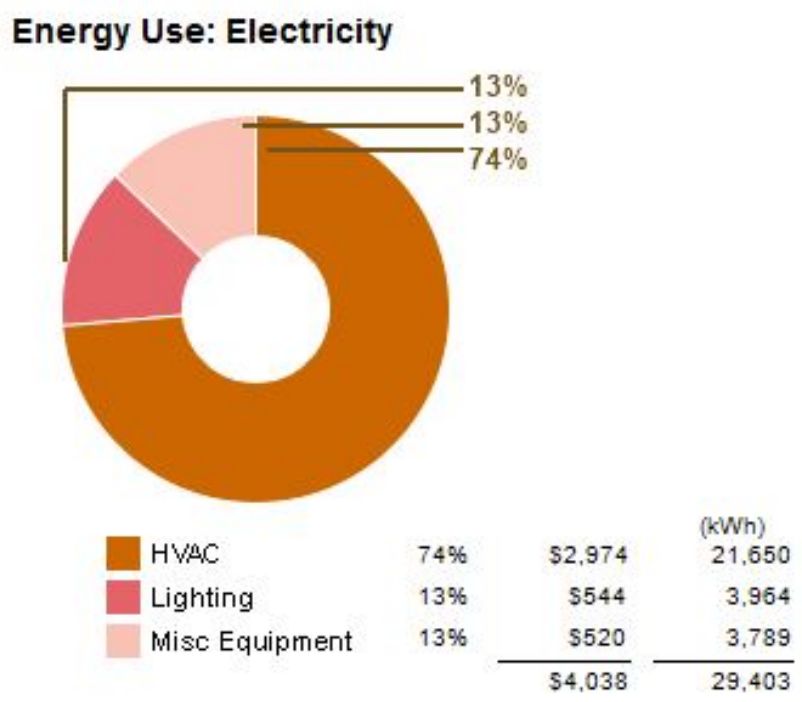

Figure 22. Total energy consumption with only low-efficient wall system

\section{Energy Use: Electricity}

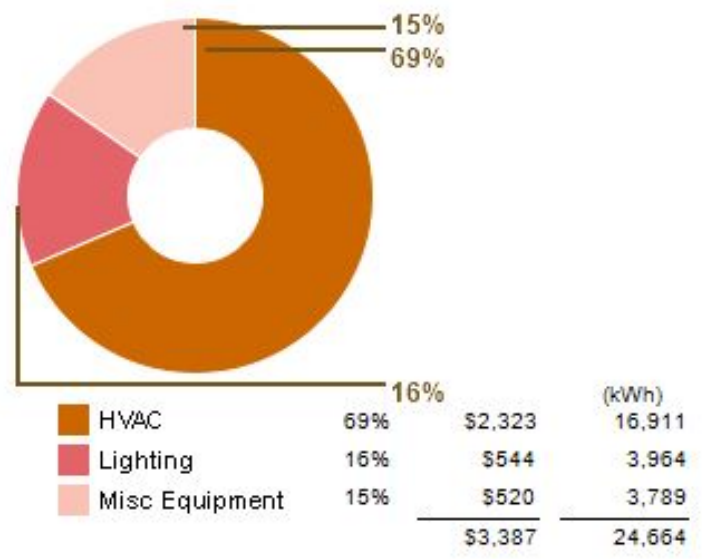

Figure 23. Total energy consumption with only no roof system's strategies

\section{Energy Use: Electricity}

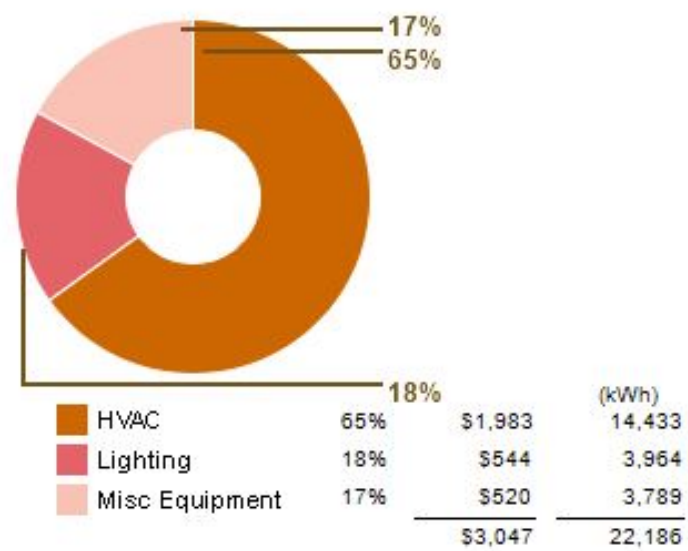

Figure 24. Total energy consumption with a clear single pane glazing

\subsection{The Design Proposal and the Traditional Design Comparison}

The comparison between the proposed design and the traditional design shows a significant difference in energy consumption. The high efficient building envelope of the proposed design makes the house consume $48 \%$ less electricity than the conventional house, which is about $18,000 \mathrm{kWh}$ less per year than the traditional home energy consumption. The difference between the design proposal and the traditional design becomes is more 
celebrated in the summer season versus the winter. The gap between the two houses' energy use is doubled in summer as is illustrated in Figure 25.

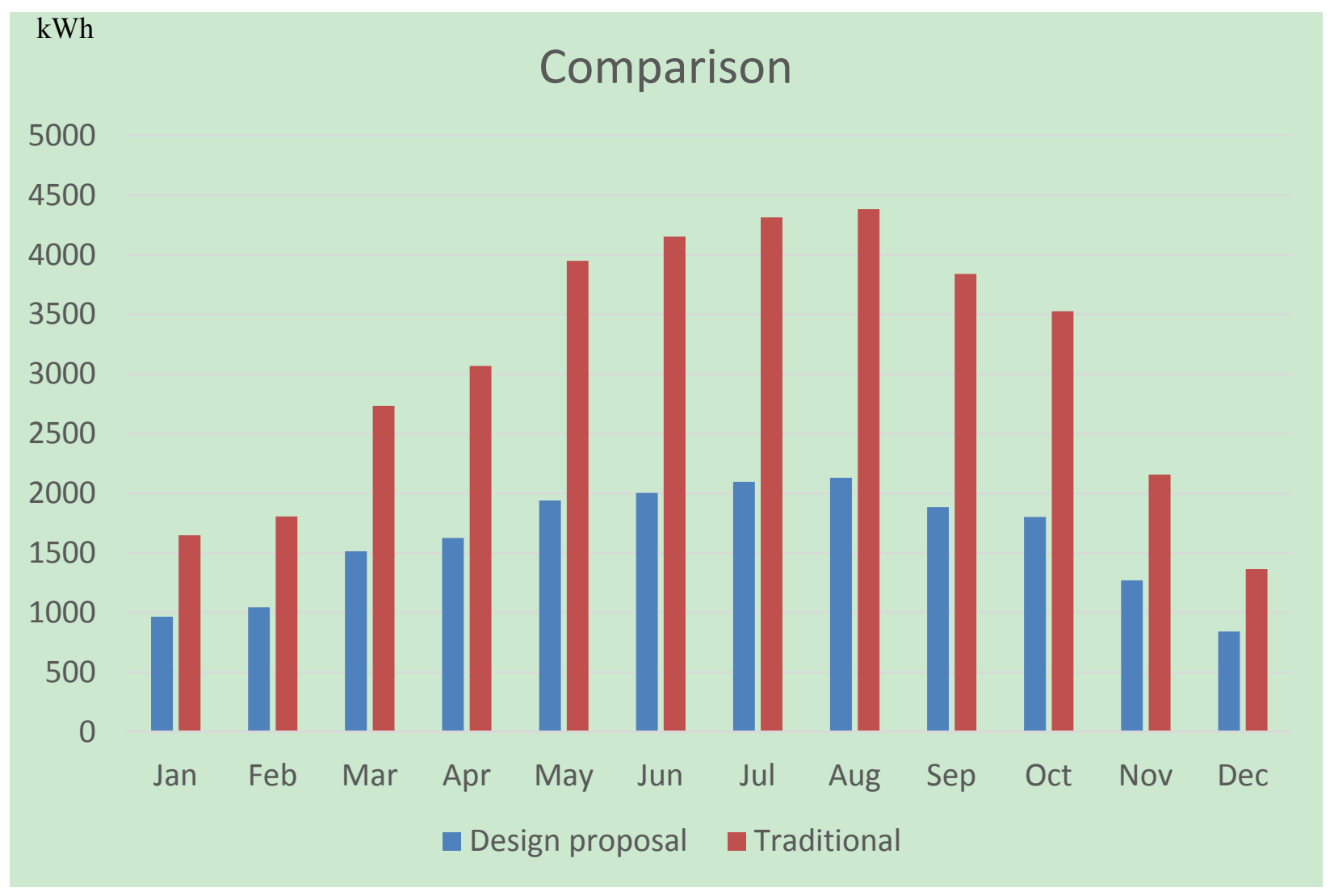

Figure 25. Comparison between the proposed design and the traditional design

\subsection{Photovoltaics System}

The simulation of the proposed design's energy consumption determined the amount of energy that the house needs. Therefore, the sufficient solar energy to generate the house demands of energy can be designed. The methods to calculate and select the proper PV are by PVWatts Calculator of the National Renewable Energy Laboratory and PVSKETCH website. Several factors can affect the PV's output, but the most compelling factors are the PV type, number, and angle. The number of PV's that are mounted is 34 , with all having a 0-degrees tilt which means it lies horizontally, and the type that is selected has an efficiency rate of $19 \%$. This 34 photovoltaics generate $13.6 \mathrm{~kW}$ which give around 23,241 kWh per year, and the house uses about 19,127 kWh of electricity per year. This photovoltaic system can generate up to $24,975 \mathrm{kWh}$ per year as expounded on in Table 4 if the angle was $20^{\circ}$; however, in this case, it will increase the energy that is generated in winter and decrease the summer production because the sun's altitude in the summer in Saudi Arabia is almost perpendicular. Thus, because of the high demand for energy in the summer for the house as is illustrated in Figure 26, the appropriate tilt should be 0 -degrees to maximize the summer production as is shown in Table 5 . 
Table 4. Photovoltaics energy generation with $20^{\circ}$ tilt (PVWatts)

\begin{tabular}{ccc}
\hline Month & $\begin{array}{c}\text { Solar Radiation } \\
\left(\mathrm{kWh} / \mathrm{m}^{2} / \text { day }\right)\end{array}$ & $\begin{array}{c}\text { AC Energy } \\
(\mathrm{kWh})\end{array}$ \\
\hline January & 5.52 & 1,890 \\
February & 6.04 & 1,834 \\
March & 6.35 & 2,125 \\
April & 6.50 & 2,053 \\
May & 7.05 & 2,236 \\
June & 7.48 & 2,273 \\
July & 7.39 & 2,327 \\
August & 7.39 & 2,297 \\
September & 7.38 & 2,232 \\
October & 7.07 & 2,254 \\
November & 5.92 & 1,858 \\
December & 4.68 & 1,596 \\
\hline Annual & 6.56 & 24,975 \\
\hline
\end{tabular}

Table 5. Photovoltaics energy generation with 0-degree tilt (PVWatts)

\begin{tabular}{ccc}
\hline Month & $\begin{array}{c}\text { Solar Radiation } \\
\left(\mathrm{kWh} / \mathrm{m}^{2} / \text { day }\right)\end{array}$ & $\begin{array}{c}\text { AC Energy } \\
(\mathrm{kWh})\end{array}$ \\
\hline January & 4.28 & 1,457 \\
February & 5.07 & 1,542 \\
March & 5.78 & 1,941 \\
April & 6.42 & 2,035 \\
May & 7.34 & 2,330 \\
June & 8.03 & 2,445 \\
July & 7.81 & 2,463 \\
August & 7.43 & 2,314 \\
September & 6.88 & 2,089 \\
October & 5.99 & 1,919 \\
November & 4.70 & 1,484 \\
December & 3.60 & 1,222 \\
\hline Annual & 6.11 & 23,241 \\
\hline
\end{tabular}

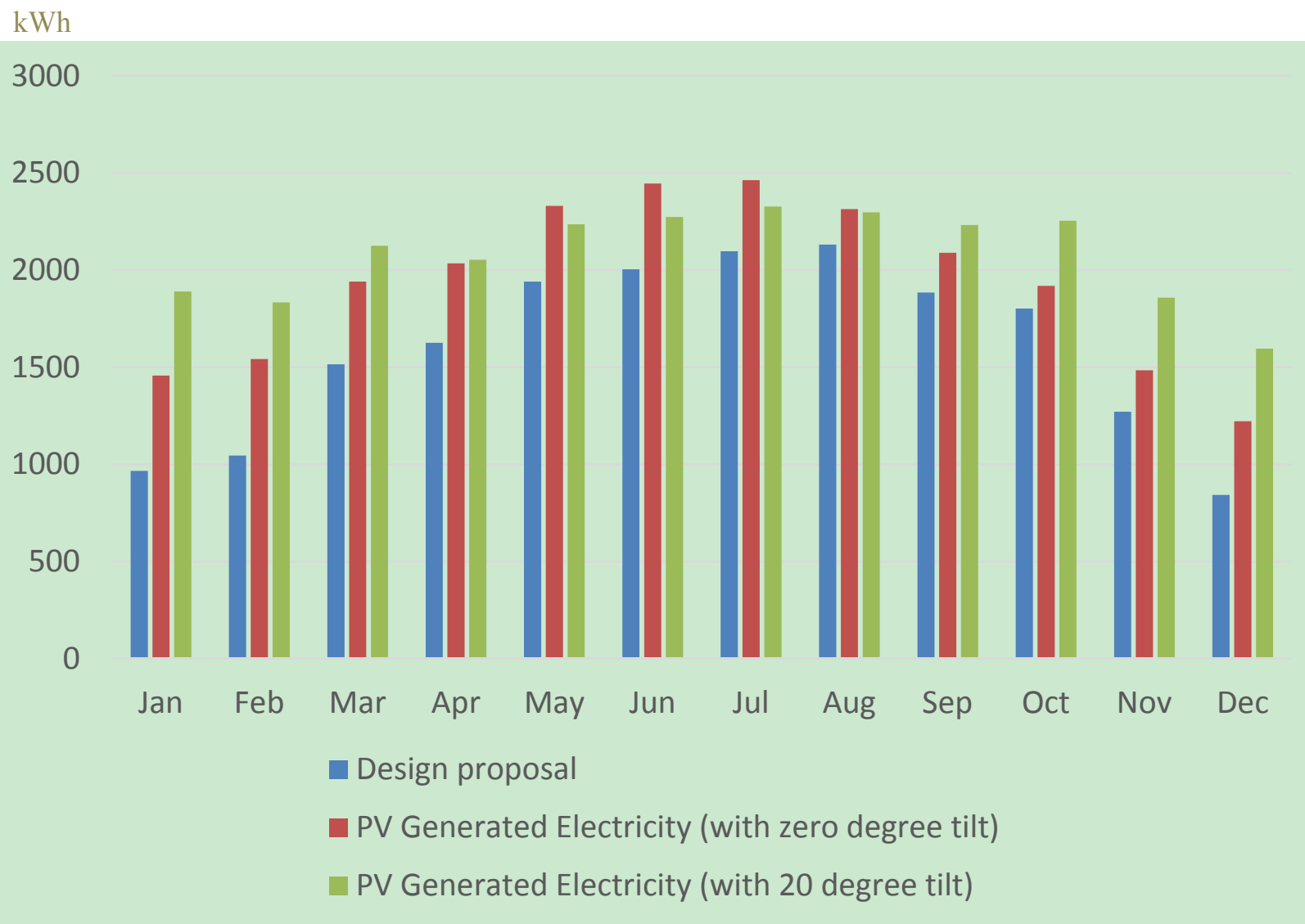

Figure 26. Photovoltaics energy generation comparison

To make the traditional house net-zero energy with the same PV condition as the one used for the proposed design, more than double the number of PVs should be added. Meeting the demand of energy that the traditional house needs to require 81 photovoltaics that generates $27 \mathrm{~kW}$, which produces around $45,255 \mathrm{kWh}$ per year as is illustrated in Table 6. The reason why it needs substantially more than it consumes is that all the extra energy is attributable to the rise of the cooling loads in summer, which requires those additional PVs to make the net-zero 
house energy as is shown in Figure 27. To install this large number of PVs, the whole house's roof should be covered by these PVs which is an unreasonable solution.

Table 6. Photovoltaics energy generation for the traditional house (PVWatts)

\begin{tabular}{ccc}
\hline Month & $\begin{array}{c}\text { Solar Radiation } \\
\left(\mathrm{kWh} / \mathrm{m}^{2} / \text { day }\right)\end{array}$ & $\begin{array}{c}\text { AC Energy } \\
(\mathrm{kWh})\end{array}$ \\
\hline January & 4.28 & 2,828 \\
February & 5.07 & 2,998 \\
March & 5.78 & 3,775 \\
April & 6.42 & 3,961 \\
May & 7.34 & 4,543 \\
June & 8.03 & 4,767 \\
July & 7.81 & 4,796 \\
August & 7.43 & 4,513 \\
September & 6.88 & 4,075 \\
October & 5.99 & 3,739 \\
November & 4.70 & 2,890 \\
December & 3.60 & 2,370 \\
\hline Annual & 6.11 & 45,255 \\
\hline
\end{tabular}

$\mathrm{kWh}$

\section{Comparison}

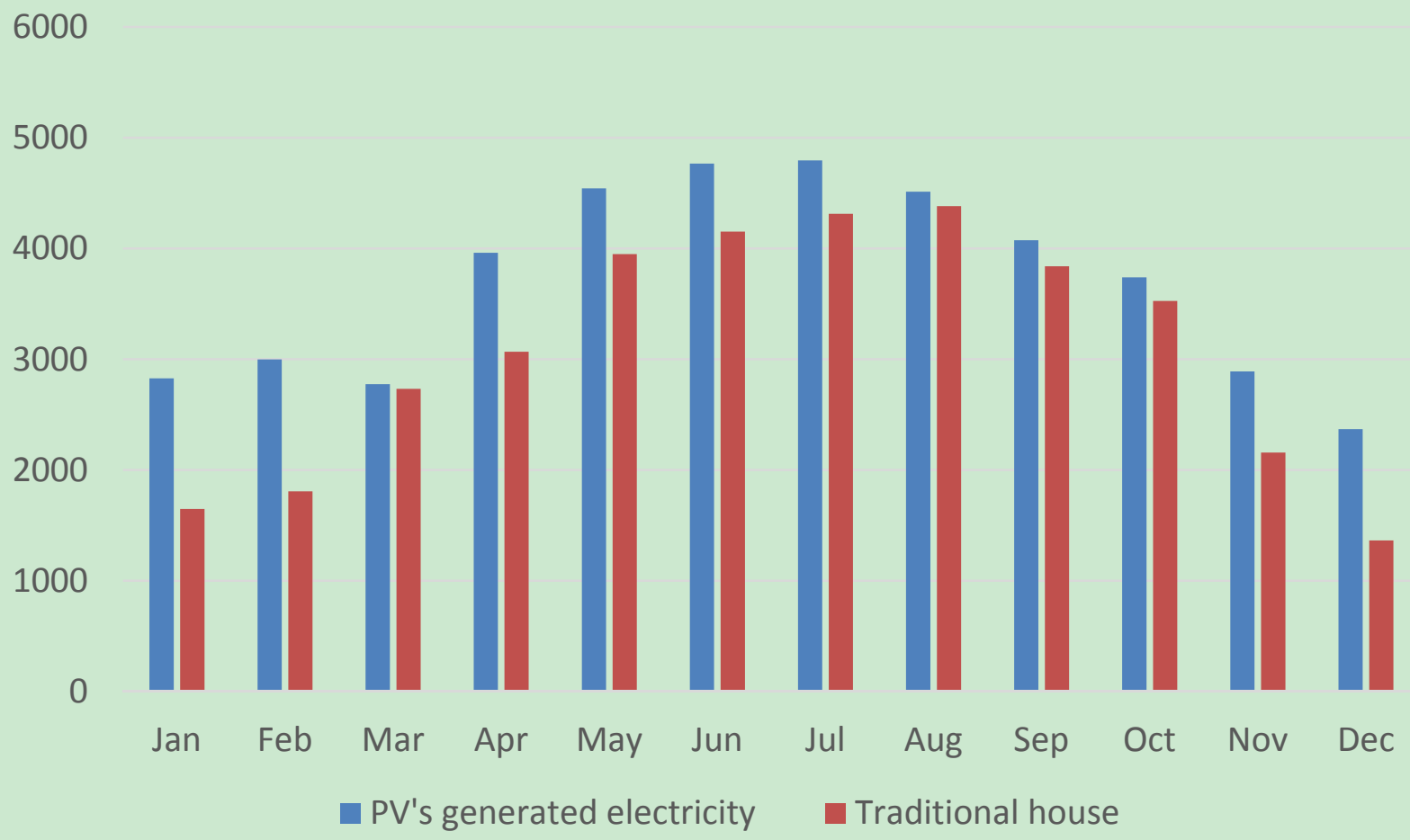

Figure 27. Comparison between PV energy generation and the traditional house's energy consumption 


\section{Conclusion}

Net-zero energy buildings are inspiring multitudes of communities, companies, and individuals presently due to their appreciating value for owners and their environmental benefits. This study aimed to show the efficacy of the building envelope to reduce the energy consumption of single-family homes in hot-dry regions. The study included several design strategies to accomplish the optimum building envelope design in hot-dry regions. Firstly, the research presented the high-performance wall system design. Secondly, the roof system and how the light, reflective color and the cool roof pond contribute to the reduction of cooling loads, which is dominant in hot-dry regions. Thirdly, the insulation system which is the most effective element of the envelope in increasing the thermal resistance (R-value). Fourthly, the fenestration system technique for the hot-dry regions that include, strategic window positioning and the appropriate window to wall ratio WWR. Fifthly, the optimal orientation of a building in a hot-dry climate. Sixthly, the courtyard design and its role to cool down the envelope. Finally, the solar panels that shaded the roof and generate the needed energy as well.

The quality of all these strategies has been documented by several researchers and cited case studies. Qatar's first Passivhaus and Vali homes Prototype I, indicated great examples of several strategies that effectively contribute to making net-zero energy houses. These procedures were applied to the proposed design and tested using BIM simulation tools. The method utilized to verify the building envelope's performance was implementing an energy simulation analysis for two identical house designs; nevertheless, their building envelope designs were different. The first was the net-zero energy house that has a high-efficiency building envelope, and the second had a traditional building envelope. The simulation results showed that the house with a high-efficient building envelope had around $48 \%$ less energy consumption than the traditional one. Therefore, making the house a net-zero energy structure became feasible with just 34 photovoltaics. Additionally, the simulation results showed that the wall system is the most efficient system of the building's envelope. Some aspects that can be useful for future research that were not covered in this paper include the cost of making a net-zero energy house in some hot-dry regions compared to a traditional home, and more variety of the envelope configuration and materials.

This study revealed that by enhancing the building envelope in hot-dry regions, achieving the net-zero energy goal can be rather easy as is expounded on in the proposed design of the house in Riyadh, Saudi Arabia. This suggested design can act as a prototype that can be adapted within most of the hot-dry regions, especially in Saudi Arabia. The aesthetics of the architectural design of the house indicated that it is not necessary to have a distasteful or bland design in order to have a net-zero energy house, but the home can, in fact, have both a high-efficient building envelope and strong visual appeal.

\section{References}

Aksamija, A. (2013). Sustainable Facades: Design Methods for High-Performance Building Envelopes (1). Somerset, US: John Wiley \& Sons, Incorporated.

Al-Sanea, S. A., \& Zedan, M. F. (2011). Improving thermal performance of building walls by optimizing insulation layer distribution and thickness for same thermal mass. Applied Energy, 88(9), 3113-3124. https://doi.org/10.1016/j.apenergy.2011.02.036

Al-Sanea, S. A., Zedan, M. F., Al-Mujahid, A. M., \& Al-Suhaibani, Z. A. (2016). Optimum R-values of building walls under different climatic conditions in the kingdom of Saudi Arabia. Applied Thermal Engineering, 96, 92-106. https://doi.org/10.1016/j.applthermaleng.2015.11.072

American, S. O. C. E. (2014). Standard ASCE/SEI 30-14: Guideline for Condition Assessment of the Building Envelope. Reston, US: ASCE.

Autodesk ${ }^{\circledR} \quad$ Sustainability Workshop. (n.d.). Glazing Properties. Retrieved from https://sustainabilityworkshop.autodesk.com/buildings/glazing-properties

Aviza, D., \& Turskis, Z. (2014). An empirical analysis of correlation between the thickness of a thermal insulation layer of the floor and the payback period. Journal of Civil Engineering and Management, 20(5), 760-766. https://doi.org/10.3846/13923730.2014.937356

Balaras, C. A., Droutsa, K., Argiriou, A. A., \& Asimakopoulos, D. N. (2000). Potential for energy conservation in apartment buildings. Energy \& Buildings, 31(2), 143-154. https://doi.org/10.1016/S0378-7788(99)00028-6

Brock, L. (2005). Designing the exterior wall: An architectural guide to the vertical envelope. Hoboken, N.J: John Wiley.

Buker, M., \& Riffat, S. (2015). Building integrated solar thermal collectors - A review. Renewable \& Sustainable Energy Reviews, 51, 327-346. https://doi.org/10.1016/j.rser.2015.06.009 
Colorado energy. $\quad$ (2016). R-Value Table. $\quad$ Retrieved from $\mathrm{http}: / / \mathrm{www}$. coloradoenergy.org/procorner/stuff/r-values.htm

Energy Consumption by Sector. (2016). Retrieved from http:/www.eia.gov/totalenergy/data/monthly/pdf/sec2_3.pdf

EU-GCC Clean Energy Technology Network. (2017). THE STRANGE AND SAD STORY OF QATAR'S FIRST PASSIVHAUS.

http://www.eugcc-cleanergy.net/sites/default/files/events/2-3May2017QNRF/03.05.2017_session_ii_3_alex _amato_qgbc.pdf

Faizi, F., Noorani, M., Ghaedi, A., \& Mahdavinejad, M. (2011). Design an optimum pattern of orientation in residential complexes by analyzing the level of energy consumption (case study: Maskan mehr complexes, tehran, iran). Procedia Engineering, 21, 1179-1187. https://doi.org/10.1016/j.proeng.2011.11.2128

Givoni, B. (1998). Climate considerations in building and urban design. New York: Van Nostrand Reinhold.

Hootman, T. (2013). Net zero energy design: A guide for commercial architecture. Hoboken, N.J: John Wiley \& Sons.

Inventory of U.S. Greenhouse Gas Emissions and Sinks. (2016, April 15). Retrieved from https://www.epa.gov/sites/production/files/2016-04/documents/us-ghg-inventory-2016-main-text.pdf

James, M., \& Bill, J. (2016). Passive house in different climates: The path to net zero. New York: Routledge, Taylor \& Francis Group.

Khalfan, M., \& Sharples, S. (2016). The present and future energy performance of the first passivhaus project in the gulf region. Sustainability, 8(2), 139-139. https://doi.org/10.3390/su8020139

Kharrufa, S. N., \& Adil, Y. (2008). Roof pond cooling of buildings in hot arid climates. Building and Environment, 43(1), 82-89. https://doi.org/10.1016/j.buildenv.2006.11.034

Kumar, A., Baredar, P., \& Qureshi, U. (2015). Historical and recent development of photovoltaic thermal (PVT) technologies. Renewable and Sustainable Energy Reviews, 42, 1428-1436. https://doi.org/10.1016/j.rser.2014.11.044

Lamba, R., \& Kaushik, S. (2016). Modeling and performance analysis of a concentrated photovoltaic-thermoelectric hybrid power generation system. Energy Conversion \& Management, 115, 288-298. https://doi.org/10.1016/j.enconman.2016.02.061

Maehlum, M. A. (2013). The History of Solar Energy - Timeline. Retrieved from http://energyinformative.org/the-history-of-solar-energy-timeline/

Manioğlu, G., \& Oral, G. K. (2015). Effect of courtyard shape factor on heating and cooling energy loads in hot-dry climatic zone. Energy Procedia, 78, 2100-2105. https://doi.org/10.1016/j.egypro.2015.11.250

Meteoblue. (n.d.). Climate Riyadh. Retrieved June 30, 2017, from https://www.meteoblue.com/en/weather/forecast/modelclimate/riyadh_saudi-arabia_108410

Morrissey, J., Moore, T., \& Horne, R. E. (2011). Affordable passive solar design in a temperate climate: An experiment in residential building orientation. Renewable Energy, 36(2), 568-577. https://doi.org/10.1016/j.renene.2010.08.013

Muhaisen, A. S. (2006). Shading simulation of the courtyard form in different climatic regions. Building and Environment, 41(12), 1731-1741. https://doi.org/10.1016/j.buildenv.2005.07.016

National renewable energy laboratory. (n.d.). Solar Photovoltaic Technology Basics. Retrieved from https://www.nrel.gov/workingwithus/re-photovoltaics.html

Olivier, D. (2000). Plugging the air leaks. In Building for a Future: Journal of the Association for Environment Conscious Building, 9(4), 16-17.

Peel, M., Finlayson, B., \& McMahon, T. (2007). Updated World Map of Koppen-Geiger Climate Classification. Hydrology and Earth System Sciences, 11(5), 1633-1644. https://doi.org/10.5194/hess-11-1633-2007

Prado, R. T. A., \& Ferreira, F. L. (2005). Measurement of albedo and analysis of its influence the surface temperature of building roof materials. Energy \& Buildings, 37(4), 295-300. https://doi.org/10.1016/j.enbuild.2004.03.009

PVWatts. (n.d.). Retrieved July 5, 2017, from http://pvwatts.nrel.gov/pvwatts.php 
Roaf, S., Fuentes, M., \& Thomas, S. (2013). Ecohouse: A design guide (4th ed.). Abingdon, Oxon: Architectural Press.

Sharifi, A., \& Yamagata, Y. (2015). Roof ponds as passive heating and cooling systems: A systematic review. Applied Energy, 160, 336-357. https://doi.org/10.1016/j.apenergy.2015.09.061

Suehrcke, H., Peterson, E. L., \& Selby, N. (2008). Effect of roof solar reflectance on the building heat gain in a hot climate. Energy \& Buildings, 40(12), 2224-2235. https://doi.org/10.1016/j.enbuild.2008.06.015

Sweet, R. (2014). Qatar begins testing its first "eco villa". Retrieved from http://www.globalconstructionreview.com/innovation/qatar-begins-testing-its-first-eco-villa4790/

U.S. Department of Energy. (n.d.). Energy Performance Ratings for Windows, Doors, and Skylights. Retrieved from https://energy.gov/energysaver/energy-performance-ratings-windows-doors-and-skylights

Weather and Climate: Riyadh, Saudi Arabia. (n.d.). Retrieved July 1, 2017, from https://weather-and-climate.com/average-monthly-Rainfall-Temperature-Sunshine,Riyadh,Saudi-Arabia

Zhu, W., Deng, Y., Wang, Y., Shen, S., \& Gulfam, R. (2016). High-performance photovoltaic-thermoelectric hybrid power generation system with optimized thermal management. Energy, 100, 91-101. https://doi.org/10.1016/j.energy.2016.01.055

\section{Appendixes}

Appendix A. Thermal resistance properties of some building materials (Aksamija, 2013)

\begin{tabular}{ll}
\hline Material & R-value (h-ft ${ }^{2} \mathbf{~}^{\mathbf{F}} \mathbf{\text { Btu}}$ ) \\
\hline Brick & $0.10-0.40$ per inch \\
CMU, 8 in. (200 mm) & $1.11-2.0$ \\
CMU, 12 in. (300 mm) & $1.23-3.7$ \\
Concrete (sand and gravel aggregate) & $0.05-0.14$ per inch \\
Concrete (limestone aggregate) & $0.09-0.18$ per inch \\
Concrete with lightweight aggregate & $0.11-0.78$ per inch \\
\hline Appendix B. R-value table (adapted from Colorado energy, 2016) \\
\hline Material & $\mathrm{R} / \mathrm{Inch} \mathrm{hr} \cdot \mathrm{ft} 2 \cdot{ }^{\circ} \mathrm{F} / \mathrm{Btu}$ \\
\hline Fiberglass Batts & $3.14-4.30$ \\
Fiberglass Blown (wall) & $3.70-4.30$ \\
Rock Wool Batt & $3.14-4.00$ \\
Rock Wool Blown (wall) & $3.10-4.00$ \\
Cellulose Blown (wall) & $3.80-3.90$ \\
Vermiculite & 2.13 \\
Autoclaved Aerated Concrete & 1.05 \\
Urea Terpolymer Foam & 4.48 \\
Rigid Fiberglass ( $>$ 4lb/ft3) & 4.00 \\
Expanded Polystyrene (beadboard) & 4.00 \\
Extruded Polystyrene & 5.00 \\
Polyurethane (foamed-in-place) & 6.25 \\
Polyisocyanurate (foil-faced) & $5.0-5.6$ \\
\hline
\end{tabular}

\section{Copyrights}

Copyright for this article is retained by the author(s), with first publication rights granted to the journal.

This is an open-access article distributed under the terms and conditions of the Creative Commons Attribution license (http://creativecommons.org/licenses/by/4.0/). 